\title{
Physico-Chemical Analysis in Surface Waters around the Closed Gaborone Sanitary Landfill in Botswana
}

\author{
R. D. Gwisai ${ }^{1,2, *}$, O. O. Areola ${ }^{1}$, E. M. Segosebe ${ }^{1}$ \\ ${ }^{1}$ Department of Environmental Science, University of Botswana, Botswana \\ ${ }^{2}$ Department of Environmental Science, Bindura University of Science Education, Zimbabwe
}

Copyright $\odot 2019$ by authors, all rights reserved. Authors agree that this article remains permanently open access under the terms of the Creative Commons Attribution License 4.0 International License

\begin{abstract}
The aim of the study was to ascertain the pollution levels in water sources in the areas surrounding the closed Gaborone landfill site. The study focused on the physico - chemical analysis of surface water resources around the closed Gaborone landfill site. The specific objectives were to determine the properties of surface water around the landfill and compare them along a transect with the water sources upslope and downslope of the landfill. Furthermore, the probable impacts of the wastes on water resources are highlighted and the levels of heavy metal contamination in surface waters around the closed Gaborone landfill are shown, in addition to compare the findings in this study with set standards (WHO, USEPA, FAO, EU, USSR and BOBS) and other yardsticks from previous studies. Due to scarcity of water resources and poor drainage water levels, five (5) existing surface water samples were collected offsite along a spatial gradient transect while the sampling interval was based on the length of the slope below the landfill. Field sampling and laboratory analysis of surface water resources was done so as to ascertain physico - chemical and heavy metal pollution levels. The findings of the investigations show that physical parameters such as $\mathrm{pH}$, Electrical Conductivity, turbidity, TDS and TCU levels at the closed Gaborone landfill are above the drinking water standards BOS 32: 2000, WHO (2004) and USEPA (1991) limits and there is a general decline in $\mathrm{pH}, \mathrm{EC}, \mathrm{TSS}, \mathrm{TVS}, \mathrm{TSD}$ and TCU with increasing distance from the landfill site. While the chemical properties show that alkalinity, nitrates, phosphates, sulphates, chlorides, calcium, magnesium, chromium, and ammonia levels for the closed Gaborone landfill are higher than BOS 32: 2000, WHO (2004) and USEPA (1991) limits indicating toxicity. The general trend patterns show that there is a general decline in alkalinity, $\mathrm{BOD}_{5}$, sulphates, phosphates, nitrates, magnesium, calcium and chromium levels with increasing distance from the closed Gaborone landfill while chlorides levels are increasing. There was a significant decline in alkalinity, EC, sulphates, and calcium with increasing distance at $P=$ 0.05 . On the other hand, $\mathrm{BOD}_{5}$ levels can be classified as
\end{abstract}

clean to moderately polluted. Overall, sanitary landfills have a far-reaching impact on the surrounding water resources and if left unmonitored increased pollution levels could lead to compromised drinking water quality, public health deterioration and descending environmental eminence.

Keywords Gaborone Landfill, Heavy Metals, Physico-Chemical, Surface Waters, Water Resources

\section{Introduction}

Initiatives in solid waste management are growing phenomenon in developing nations that have created employment (Areola, Segosebe and Gwisai, 2015; Strange, 2002; Abdelatif, 2001; Abd Malek et al., 1996). On the other hand, the under - privileged have found opportunities to earn a living from landfill sites (Areola, Segosebe and Gwisai, 2015; Manyanhaire et al., 2009; Masocha and Tevera, 2003). However, it has been observed that most employees in the sector have limited to no personal protective equipment. This poses serious risks on health hazards (Areola, Segosebe and Gwisai, 2015; Noel, 2010). Several studies note that limited attention has been granted towards investigations involving human health risks to which scavengers are exposed to (Areola, Segosebe and Gwisai, 2015; Noel, 2010; Chattopadhyay, Dutta and Ray, 2008; Mwiganga and Kansiime, 2005; Chofqi, et al., 2004) and to the human health concerns of the communities residing in the neighbourhoods of landfills (Gwebu, 2003). According to Elliot (2006), 80\% of the population in developed nations live within a 2 - kilometre radius of a current or closed landfill site and have experienced serious health effects. In this regard, the closed Gaborone landfill site in Botswana, has been criticized poor waste operations and management (The Botswana Gazette, 2010; Ngole, 2000). In Botswana, generally there are fewer engineered landfill sites than dump sites (Gwebu, 2003); a situation 
which makes the environmental health risks associated with waste disposal a major public concern.

Although sanitary landfill sites have been observed to constitute a potential hazard to the environment (Khan and Agarwal, 2006; Misra and Pandey, 2004; Christensen and Christensen, 1999; Moyo et al., 1993), in many cases, the effects of the landfills are not easily discernible. The pertinent effects include ground and surface water pollution (Areola, Segosebe and Gwisai, 2015; Odukoya and Abimbola, 2010; Miller, 1996). Health risk related studies on employees in the handling, transporting, clean-up or maintenance of substances at landfill sites have been found to be very scarce. Yet, many chemicals present in landfill sites have been shown to have adverse effects on human health (Vrijheid, 2000). Hence, the focus of this study was to examine the environmental pollution challenges in surface water resources in and around municipal landfill sites as revealed in some studies (Areola, Segosebe and Gwisai, 2015). The concern for the plight of surface water resources near landfills is partly due to the lower levels of public awareness and respect for public opinion in decision making in developing countries as compared to what obtains in the developed world. Indeed, there are instances in some countries where governments and government officials have deliberately accepted the dumping of hazardous wastes at some locations in the developing world (Areola, Segosebe and Gwisai, 2015).

The aim of the study was to investigate and evaluate the surface water pollution levels of surface water resources nearby the closed Gaborone Municipal landfill. These investigations were based on the Gaborone landfill in Botswana in the southern African region of the continent. The specific objectives of the study were to determine the level of contamination, around the landfill sites by analyzing specifically the types and levels of physico chemical elements pollution and heavy metal contaminants in surface water sources around the Gaborone landfill site. Furthermore to establish how physico - chemical properties and heavy metal concentrations in the closed Gaborone surface water sources compare with other yardsticks from previous studies and set standards (e.g. Areola, Segosebe and Gwisai, 2015; Matsa and Mutekwa, 2009; Odukoya and Abimbola, 2010).

Waste management has been one of the core values of the National Development Plan, NDP 10, in Botswana, which aimed at achieving the sustainable development goal. Thus, this study would contribute to knowledge specifically by helping to identify the primary chemical and heavy metals that constitute the major hazards. Such knowledge would help governments and international organizations to develop appropriate mitigation or otherwise intervention measures as an aftermath of the decommissioning of landfills and dumpsites. Urbanization levels in Gaborone could have a significant influence on waste types and quantities and therefore pollution levels of water resources in the surrounding environment as shown in other studies (Areola, Segosebe and Gwisai, 2015). With the notion of almost two decades after the development of the landfill disposal ideology, legislation and implementation in 1998, it is necessary to carry out an audit on water contaminations related issues that will contribute to new knowledge on the impacts of landfills specifically on the surface water resources as recommended by other studies (Areola, Segosebe and Gwisai, 2015; Ngole, 2000).

\section{Study Area}

Botswana is located in the southern part of the African continent. It is bounded to the south and southeast by South Africa, to the west by Namibia, to the north by Zambia and to the northeast by Zimbabwe. The closed Gaborone landfill site was commissioned in 1993 close to the Gaborone dam and the Notwane river catchment area is one of the landfill sites that was commissioned before landfill legislature in 1998 (Government of Botswana, 1998). The landfill which served the capital city of the country was commissioned without a landfill leachate liner while management operations were poor and done haphazardly (Gwebu, 2003). Therefore the main focus of the study was to assess landfill site impacts, and the extent to which these pollutants have contaminated the environment and human health (Ngole, 2000). Gaborone landfill appeared to lack a lot of equipment that could have ensured a smooth running of operations, and this led to shortage of space in waste cells, possibilities of finding an admixture of items in the same zone of the landfill, and rare waste compaction (Ngole, 2000; Gwebu, 2003). The closed Gaborone landfill site is undergoing rehabilitation. Assessing the effects of landfill pollutants at this stage of the landfill site may act as a guide to future landfill rehabilitation programmes, which Local Authorities (LAs) and the central government may wish to take note of as this may reduce operational costs of landfill sites and help to develop sustainable economic budgets. The temperatures and rainfall have an influence on the biochemical reactions taking place in the landfill sites. This results in varying pollutant production rates affecting the environment and human health (Areola, Segosebe and Gwisai, 2015; Lobatse Town Council, 2002). 


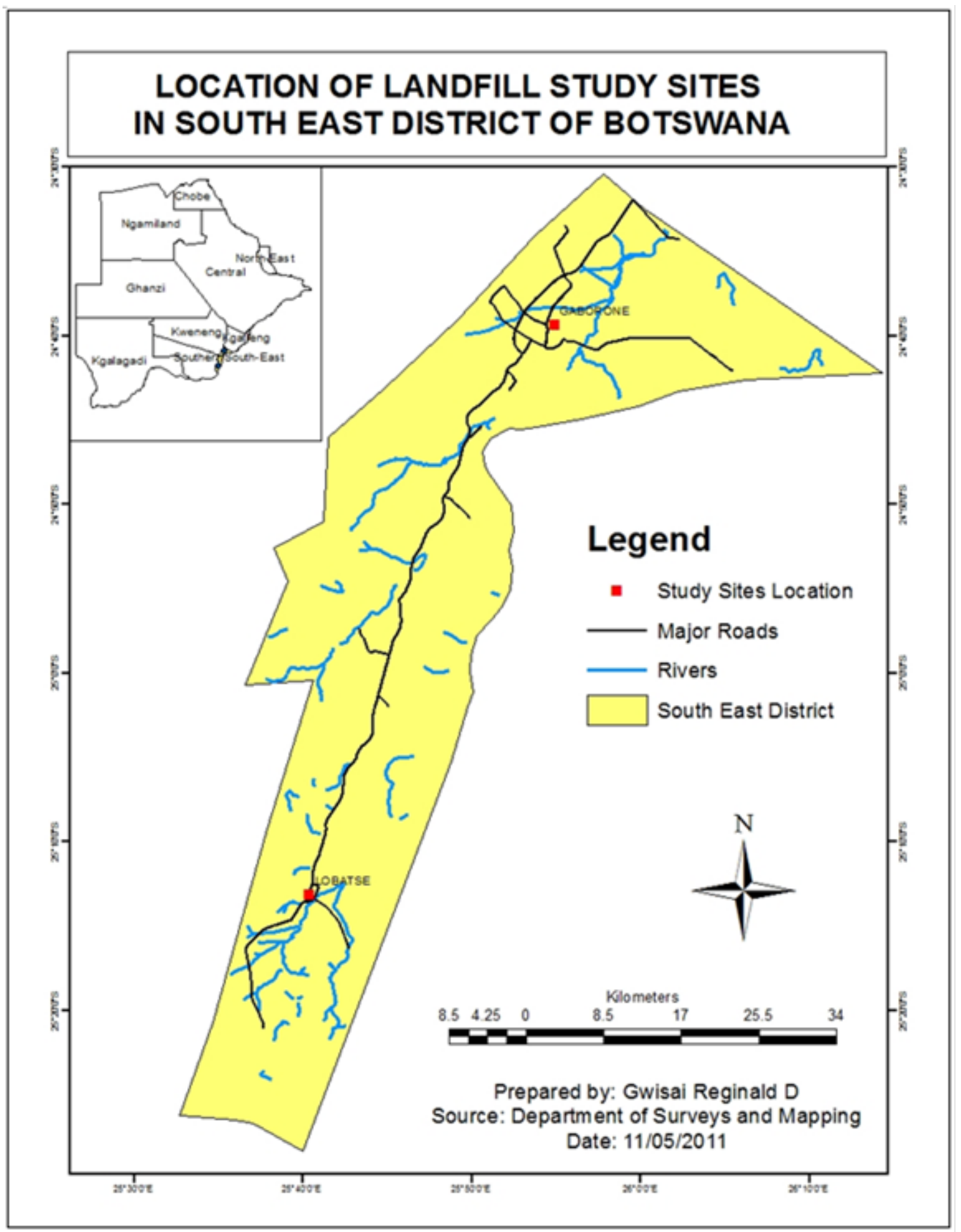

Figure 1. Map of Study Area 


\section{Materials and Methods}

Due to scarcity of water resources and poor drainage water levels, five (5) existing surface water samples were collected offsite along a spatial gradient transect while the sampling interval was based on the length of the slope below the landfill. Field sampling and laboratory analysis of surface water resources was done so as to ascertain physico - chemical and heavy metal pollution levels. The basic principle followed was sampling from the landfill down to the foot of the slope below it. Surface water samples were collected (bulk sampling) from the existing water sources around the landfill sites A control sample from upslope was collected for comparative purposes. Figure 2 shows the sampling points at varying distances. The parameters measured were $\mathrm{pH}$, colour (TCU), total solids (TS), total suspended solids (TSS), total dissolved solids (TDS),Biological Oxygen Demand $\left(\mathrm{BOD}_{5}\right)$, Chemical Oxygen Demand (COD), alkalinity, Biological Oxygen Demand $\left(\mathrm{BOD}_{5}\right)$, Chemical Oxygen Demand(COD), alkalinity, conductivity (EC), phosphates $\left(\mathrm{PO}_{4}^{3-}\right)$, sulphates $\left(\mathrm{SO}_{4}^{2-}\right)$, ammonia $\left(\mathrm{NH}_{3}\right)$, nitrates $\left(\mathrm{NO}_{3}^{-}\right)$ and chlorides $\left({ }_{17}^{36} \mathrm{Cl}^{-}\right)$(APHA, 1995).Pollutant characterization may involve both quantitative and qualitative determination of heavy metal cations. The following metals were assessed; iron $\left({ }_{26}^{56} \mathrm{Fe}^{2+}\right)$, manganese $\left({ }_{25}^{55} \mathrm{Mn}^{2+}\right)$, copper $\left({ }_{29}^{64} \mathrm{Cu}^{2+}\right)$, zinc $\left({ }_{30}^{65} \mathrm{Zn}^{2+}\right)$, lead $\left({ }_{82}^{207} \mathrm{~Pb}^{2+}\right)$, chromium $\left({ }_{24}^{52} \mathrm{Cr}^{6+}\right)$, nickel $\left({ }_{28}^{59} \mathrm{Ni}^{2+}\right)$, sodium $\left({ }_{11}^{23} \mathrm{Na}^{+}\right)$, magnesium $\left({ }_{12}^{24} \mathrm{Mg}^{2+}\right)$, potassium $\left({ }_{19}^{39} \mathrm{~K}^{+}\right)$, calcium $\left({ }_{20}^{40} \mathrm{Ca}^{2+}\right)$ as these have been found to be common in other related landfill studies conducted earlier (Areola, Segosebe and Gwisai, 2015; Nwachukwu et al., 2010). The main analytical tool used was the Atomic Absorption
Spectrophotometer (AAS). The Flame AAS was used to determine the concentration of the metals selected above. The AAS technique basically involves the principle of free atoms in elements that will absorb light at wavelength characteristics of that element which is determined by the outer electron structure (Areola, Segosebe and Gwisai, 2015; Ngole, 2000; Alloway, 1995). The amount of light is directly proportional to the concentration of the element in solution. The absorbance is normally measured and is used to determine the concentration of the specific element. Normally the solution is atomized in a flame in the Flame AAS.

\section{Results and Discussions}

\section{Surface Water Physico-Chemical Pollution}

Five (5) surface water samples were measured for $\mathrm{pH}$, which ranged from $7.88-8.75$ (Figure 2). All the samples recorded higher $\mathrm{pH}$ values than the standard $\mathrm{pH}$ values of 6.5 patently rendering them unsuitable for drinking purposes (Table 2), (BOS 32:2000; WHO, 2004; USEPA, 1991). The highest $\mathrm{pH}$ value recorded was 8.39 at a distance of $0.2 \mathrm{~km}$ downstream which is similar to other studies. However, there is complementary literature that shows surface water sources in other landfills having $\mathrm{pH}$ levels in the acidic to alkaline range which also signals unsuitability for drinking and pollution of the water sources (Areola, Segosebe and Gwisai, 2015; Longe and Balogun, 2010; Raman and Sathiya - Narayanan, 2008; Longe and Enekwechi, 2007; Haertling, 1989).

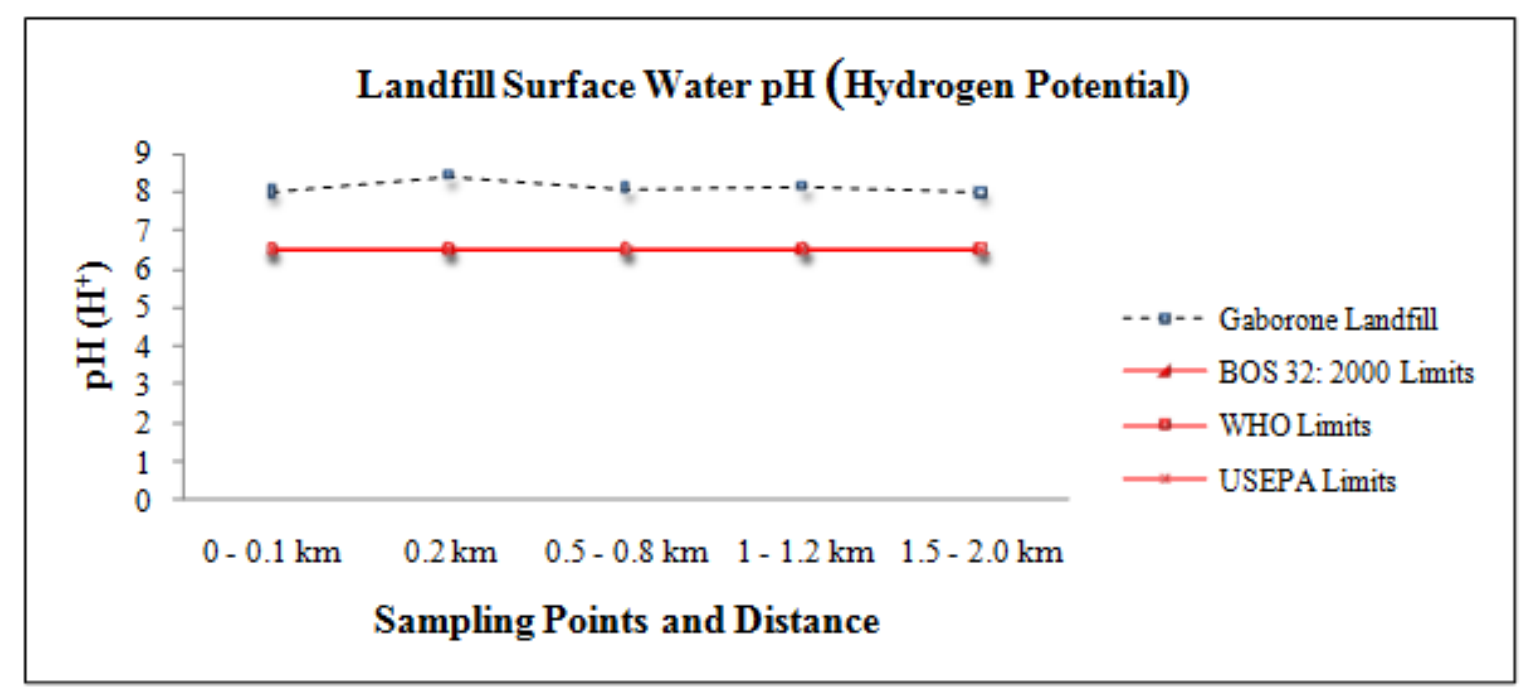

Figure 2. Landfill Surface Water $\mathrm{pH}$ 


\section{EC $\left(\mu \mathrm{S} \mathrm{cm}^{-1}\right)$ Levels}

Electrical Conductivity (EC) was measured at $25^{\circ} \mathrm{C}$ and all the surface water samples were in the range of $189.2-$ $1577.70 \mu{\mathrm{S} . \mathrm{cm}^{-1}}^{-1}$ All the samples were below the recommended drinking water standard BOS 32: 2000 value of 3100 $\mu \mathrm{S} . \mathrm{cm}^{-1}$ (Figure 3) as observed by Areola, Segosebe and Gwisai (2015). This could have been because the Lobatse landfill is in the same geographical area and have similar rainfall and temperature patterns. On the other hand, this is contrary to findings by previous studies which found EC levels to be above the set EU limits (Table 2), (Alslaibi, Mogheir and Afifi, 2011; Al - Rawas and Valeo, 2011; Osei et al., 2011; Al - Sabahi et al., 2009; Salminen, 2005; Jeevan Rao and Shantaram, 2003).

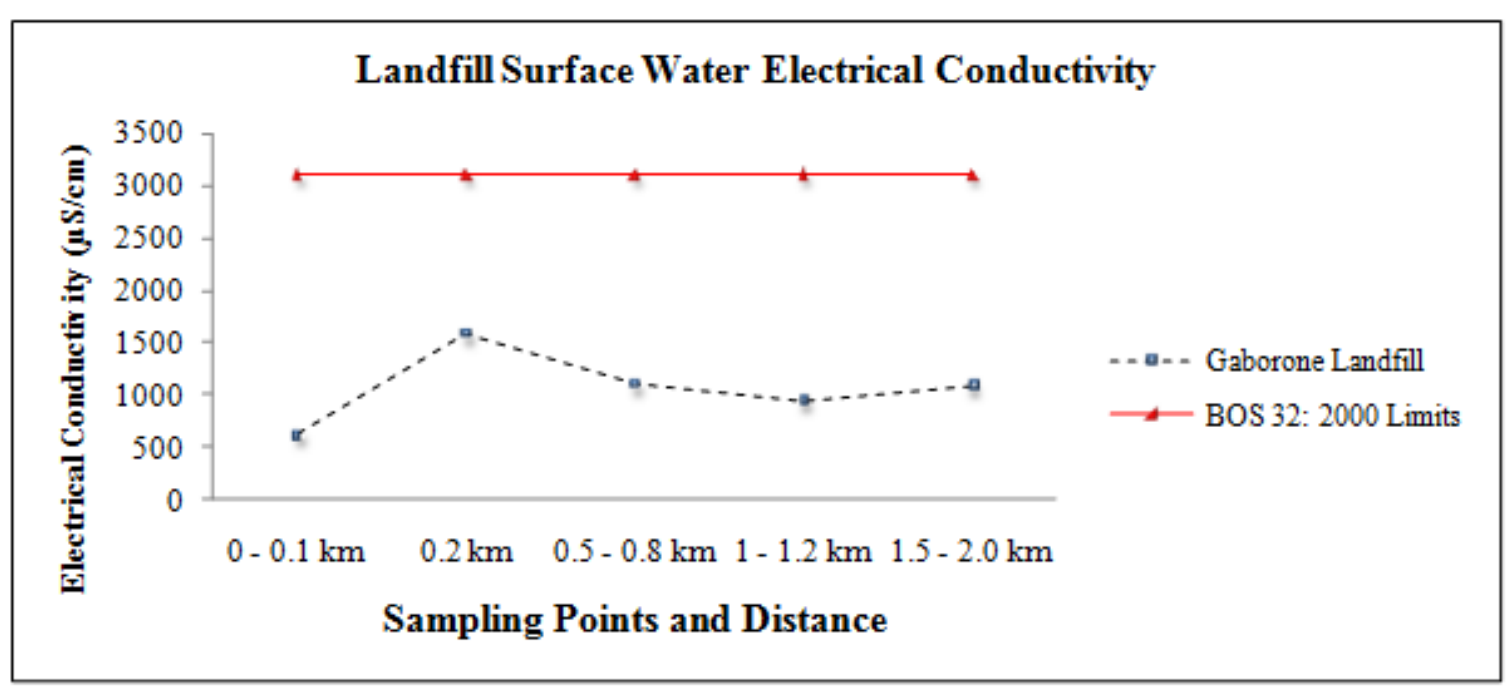

Figure 3. Landfill Surface Water Electrical Conductivity

\section{Colour (TCU) Levels}

The colour of surface water samples was measured using the True Colour Units (TCU), and all the samples were in the range $11-18 \mathrm{TCU}$ with some samples surpassing the set drinking water standards of 15 TCU (BOS 32:2000; USEPA, 1991). At Gaborone only one sample $(0.2 \mathrm{~km})$ surpassed the standard (Figure 4$)$. There is a general decline in colour units with increasing distance from the landfill signaling limited spatial influence of anthropogenic activities further away from the landfill sites. The trend is similar to that of other studies on wells around landfill sites (Areola, Segosebe and Gwisai, 2015; Akinbile, 2012; Raman and Sathiya - Narayan, 2008).

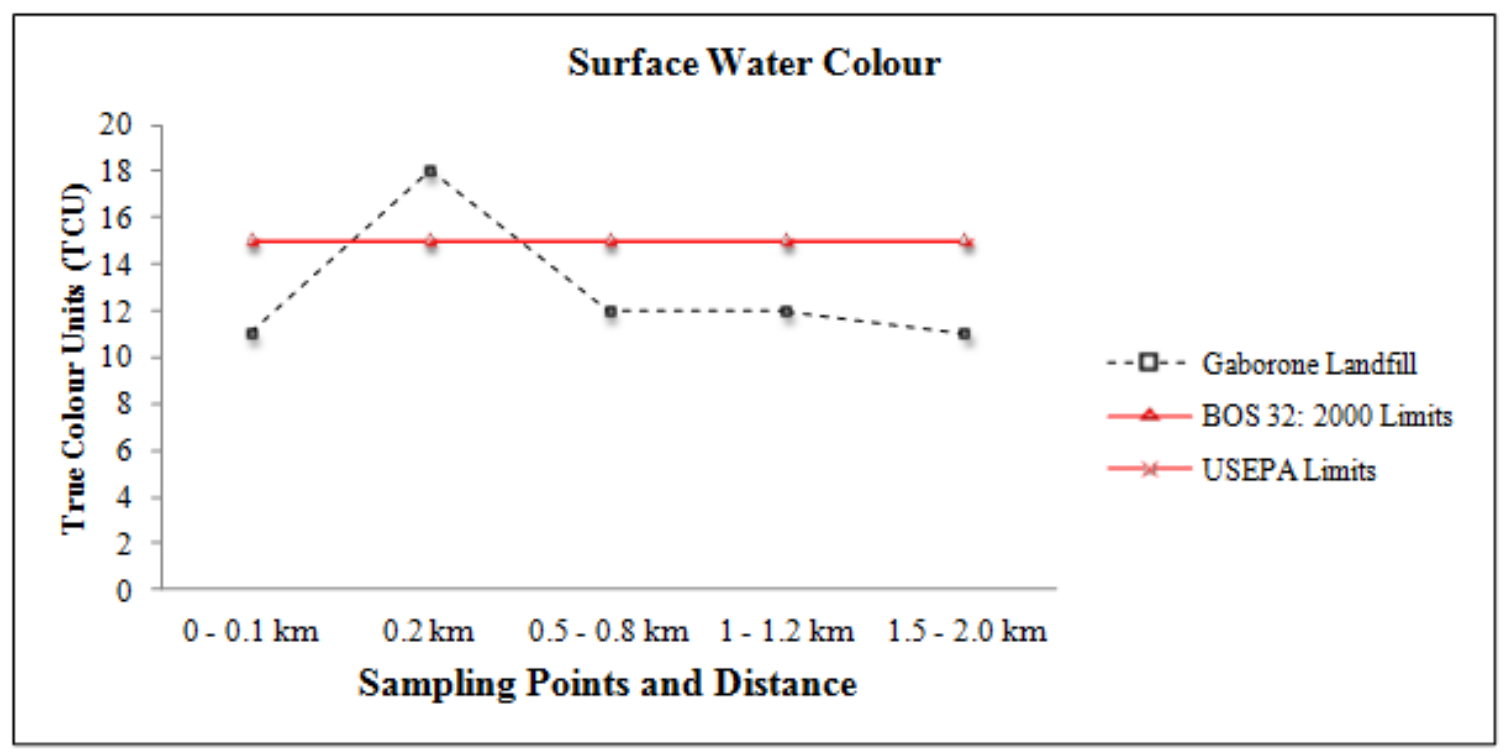

Figure 4. Surface Water Colour 


\section{Total Solids (TDS, TSS, TVS, TFS, TSD) Levels}

The range of Total Dissolved Solids (TDS) is between 110 - $1015 \mathrm{mg}$ which appears similar to those of previous studies (Akinbile, 2012; Longe and Enekwechi, 2007). All samples from Gaborone landfill have total solids more than the set drinking water standards (450 - 500 mg) (see Figure 5 and Table 5.7). The high amounts of TDS could decrease water palatability and cause gastro - intestinal irritation in humans (Al - Sabahi et al., 2009; WHO, 2004). However, some studies showed TDS values lower than the set drinking water standards (Areola, Segosebe and Gwisai, 2015; Longe and Balogun, 2010; NSDQW, 2007; WHO, 2004).

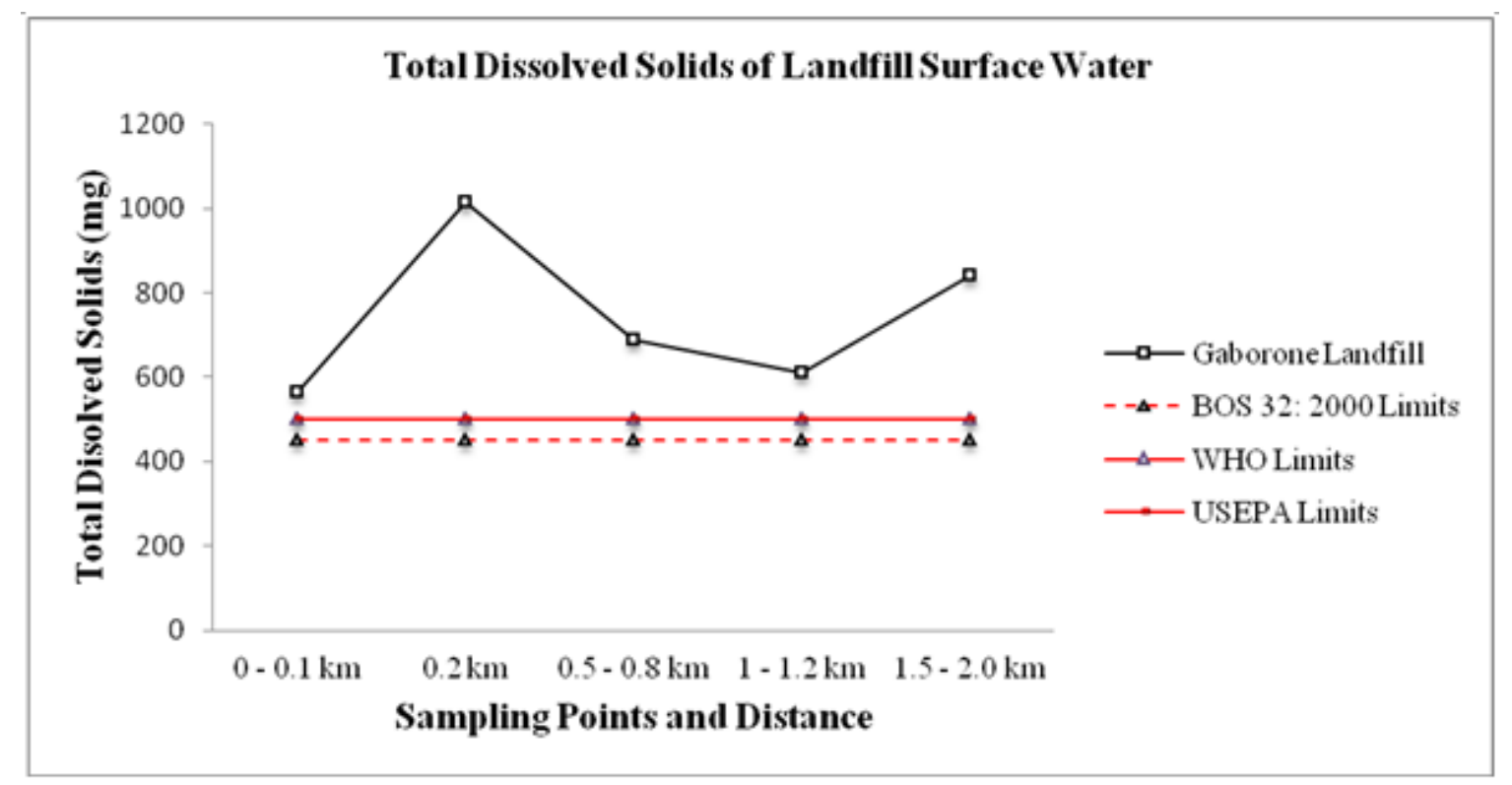

Figure 5. Total Dissolved Solids of Landfill Surface Water

Total Suspended Solids (TSS) in Gaborone (Figure 6) are below the findings in prior studies (Areola, Segosebe and Gwisai, 2015; Raman and Sathiya - Narayanan, 2008). However, there is a general decline in TSS with increasing distance from the landfill, perhaps as the influence of the waste dump and other anthropogenic factors wears off (Bada and Olarinre, 2012; Joel and Amajuoyi, 2009; Domska and Warechowska, 2008).

The Total Volatile Solids (TVS) are in the same range for all samples in Gaborone landfill. Gaborone samples show a significant gradual increase in TVS with increasing distance from the landfill $\left(r=0.9244, p=\leq 0.05\right.$ with a $\left.R^{2}=0.8545\right)$, (Figure 6). Again this could also be attributed to the amounts of wastes disposed of at the landfills and other independent human activities directly related to waste disposal at the Gaborone landfill site (Osei et al., 2011; Edosomwan and Onwumah, 2008; Wong, 1988).

There is a limited amount of Total Fixed Solids (TFS) in all Gaborone samples $(0.0032-0.0098 \mathrm{mg})$, (Figure 6). This could be due to limited spread of materials in semi - arid environments such as Botswana (Alslaibi, Mogheir and Afifi, 2011).

Also for Total Solids Dried (TSD) the range is $460-1040 \mathrm{mg}$ and there is an increase in the amount of TSD with increasing distance at Gaborone landfill site (Figure 6). The influence of other media (other than the landfill) in transporting waste and soil materials into surface waters could be prevailing in increasing TSD load (Miguel et al., 2012; Johnson and Zhang, 2012; Wuana and Okieimen, 2012;Alslaibi, Mogheir and Afifi, 2011). 

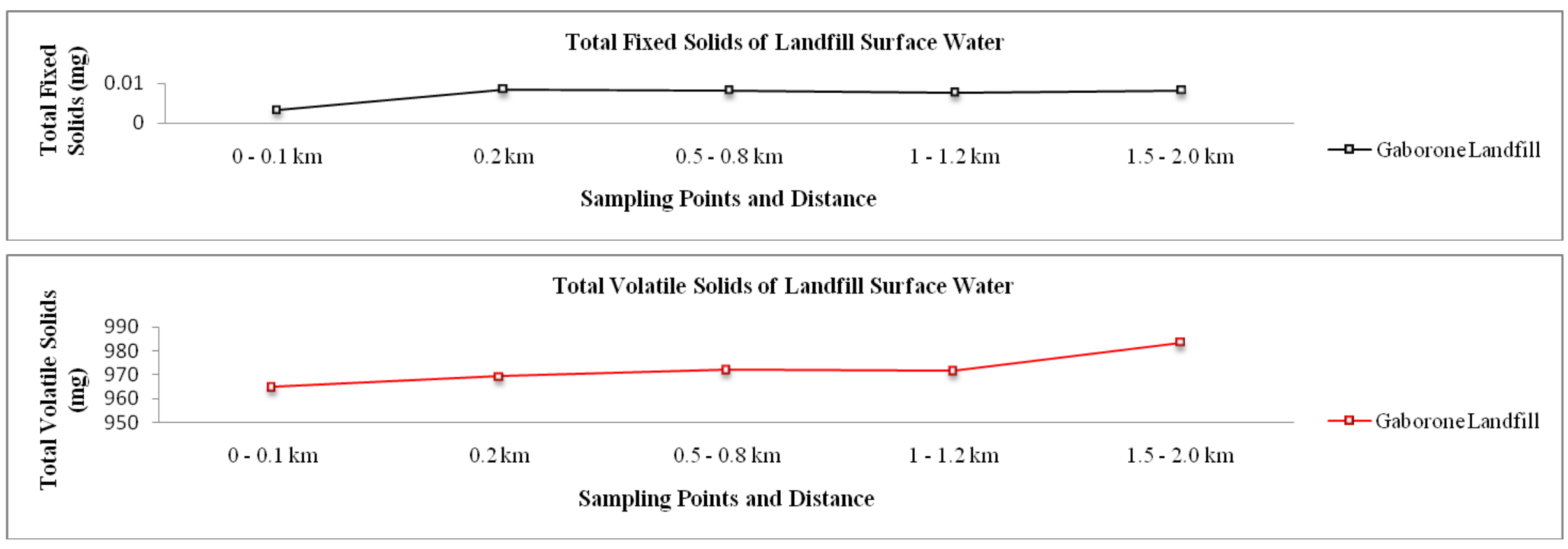

\begin{tabular}{|c|c|c|c|c|c|c|}
\hline \multirow{3}{*}{ 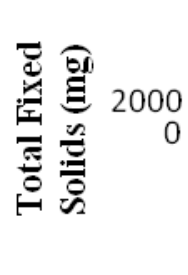 } & \multicolumn{5}{|c|}{ Total Solids Dried of Landfill Surface Water } & \multirow{3}{*}{$\rightarrow-$ GaboroneLandfil } \\
\hline & $0-0.1 \mathrm{~km}$ & $0.2 \mathrm{~km}$ & $0.5-0.8 \mathrm{~km}$ & $1-1.2 \mathrm{~km}$ & $1.5-2.0 \mathrm{~km}$ & \\
\hline & \multicolumn{5}{|c|}{ Sampling Points and Distance } & \\
\hline
\end{tabular}

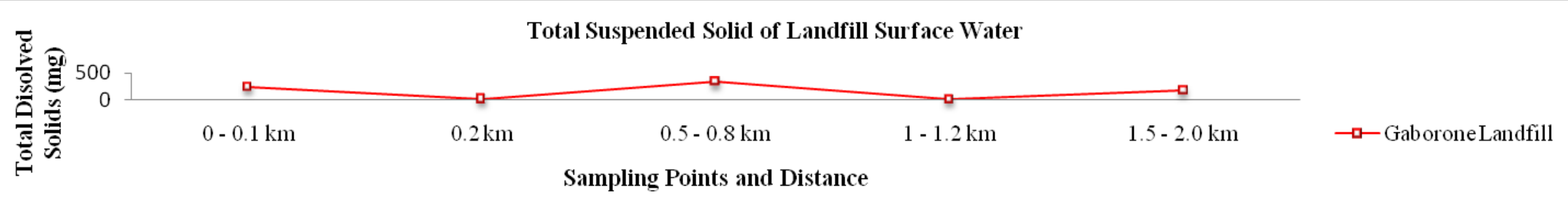

Figure 6. Gaborone Landfills Solids Levels 


\section{Turbidity (NTU)}

Turbidity was measured using Nephelometric Turbidity Units (NTU) and the samples from Gaborone have a turbidity range of $1.65-11$ NTU (Figure 7). Some studies show a higher turbidity than the present study signaling a lesser impact universally (Osei et al., 2011). On the other hand studies in Lobatse show a lower NTU levels although in a similar range (Areola, Segosebe and Gwisai, 2015). Among the Gaborone samples the level of turbidity increased downstream with increasing distance from the landfill. The level of pollution in Gaborone is higher than that of other studies (Areola, Segosebe and Gwisai, 2015), while on the other hand it increases with distance from the landfill as opposed to other studies observed (Areola, Segosebe and Gwisai, 2015; Akinbile, 2012). This could be attributed to several factors chief being other sources around the surface water points independent of the landfill which could have produced more waste materials leading to high turbidity values (Loncnar et al., 2010; Tamunobereton - ari, Omubo - Pepple and Tamunobereton - ari, 2010; Schenato, Schroder and Martins, 2008; Wuana and Okieimen, 2012; Osei et al., 2011; Alslaibi, Mogheir and Afifi, 2011; Steinnes et al., 1997). Also perhaps to a lesser extent this could be due to the influence of the landfill considering the volume of waste disposed of at the Gaborone landfill and a steep gradient from the landfill mounds to the surface water points.

The majority of samples have an unobjectionable odour except one sample from Gaborone landfill at $0.2 \mathrm{~km}$ (Figure 7). This differed from the findings of other studies (Areola, Segosebe and Gwisai, 2015; Akinbile, 2012) where most of the water samples in wells around landfills had a mild odour or none at all. All turbidity readings are above the BOS 32: 2000 drinking water limits of Botswana signifying pollution of surface water around both landfills (Table 2). For Gaborone, some of the samples are above the USEPA, WHO and BOS 32: 2000 limits (Table 2), (Raman and Sathiya - Narayanan, 2008; WHO, 2004; Radojevic and Bashkin, 1999; USEPA, 1991). The high turbidity values could be an indication of pollution from other sources and the landfill as observed in other studies (Shyamala, Shanti and Lalitha, 2008) as both the landfill and surface water boundaries are not lined. Another observation is that waste and soil cover material could find its way to the surface water just as observed by prior studies hence increasing turbidity as these are not protected water reservoirs due to proximity to the landfill (Akinbile, 2012; Mohamed et al., 2009; Jaji et al., 2007). Generally Gaborone landfill have polluted the surface water around them and the water may need to be treated before any form of use is recommended as observed in other studies (Areola, Segosebe and Gwisai, 2015; Akinbile, 2012; Ogedengbe and Akinbile, 2004).

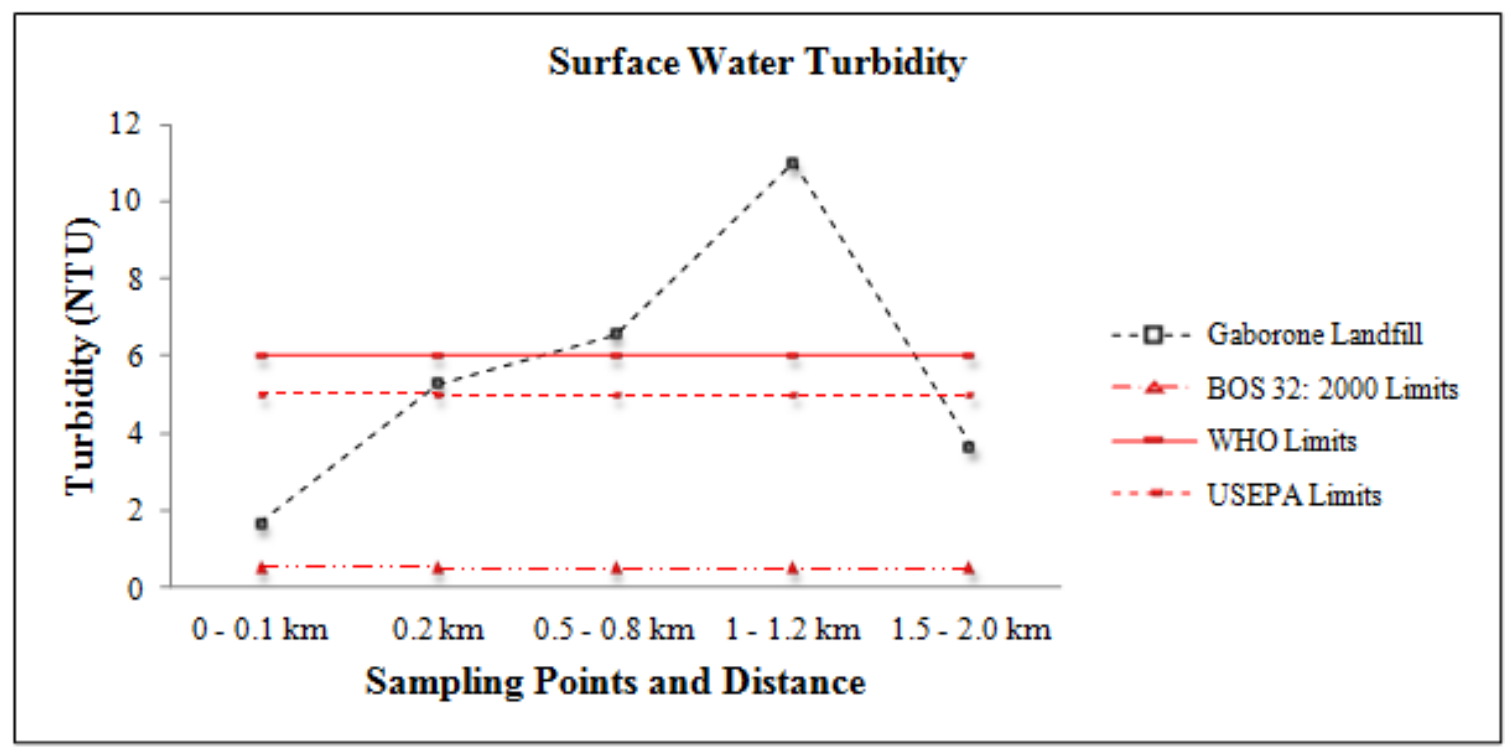

Figure 7. Surface Water Turbidity 


\section{Chemical Pollution Levels of Surface Water Samples}

\begin{abstract}
Alkalinity
Alkalinity of the Gaborone samples is in the range, $200-$ $1101 \mathrm{mg} . \mathrm{l}^{-1}$. The majority $(90 \%)$ of the samples are above the set drinking water alkalinity limits for Botswana (Figure 8 and Table 2) and also above other countries' thresholds (150 mg. $\left.\mathrm{l}^{-1}\right)$, indicating toxicity in surface water around the landfill sites (Jeevan Rao and Shantaram, 2003; BOS 32: 2000; Le Seur Spencer and Drake, 1987; WHO, 1984; ISI, 1983). Gaborone samples have higher alkalinity levels than the previous studies (Areola, Segosebe and Gwisai, 2015), although they are similar trend to previous studies conducted (Areola, Segosebe and Gwisai, 2015; Raman and Sathiya - Narayanan, 2008). The alkalinity levels could be largely attributed to waste disposed of at the landfill sites (Bhambulkar, 2011). Furthermore, there is a significant general decline in alkalinity levels with increasing distance from the landfill sites $(\mathrm{r}=-0.9382, \mathrm{p}=$ $\leq 0.05$ with a R2 $=0.8802)$, as other studies observed (Miguel et al., 2012; Wong and Leung, 1989).
\end{abstract}

\section{Biological Oxygen Demand $\left(\mathrm{BOD}_{5}\right)$}

The Biological Oxygen Demand $\left(\mathrm{BOD}_{5}\right)$ measured among the surface water samples is from $1.4-2.5 \mathrm{mg} . \mathrm{l}^{-1}$ for all the samples at the landfill site (Figure 9). The levels are below the set standard in Russia of $3.0 \mathrm{mg} . \mathrm{l}^{-1}$ although they have a similar range to other studies elsewhere (Areola, Segosebe and Gwisai, 2015). On the other hand Gaborone $\mathrm{BOD}_{5}$ levels are also below the levels in other surface waters studied by others (Osei et al., 2011; Sholichin, 2012; Alslaibi, Mogheir and Afifi, 2011; Radojevic and Bashkin, 1999). This shows that samples from the landfill are in the range of between clean and moderately polluted (Table 1). However, as to be expected the general trend for shows that there is a decline in $\mathrm{BOD}_{5}$ downstream with increasing distance from the landfill sites. As observed by Husain, Hoda and Khan, (1989) there is an increase in the concentration of pollutants closer to the landfill downstream although the $\mathrm{BOD}_{5}$ concentrations are higher as compared to the present study. On the other hand some studies concur with the findings of this study (Areola, Segosebe and Gwisai, 2015; Bhambulkar, 2011).

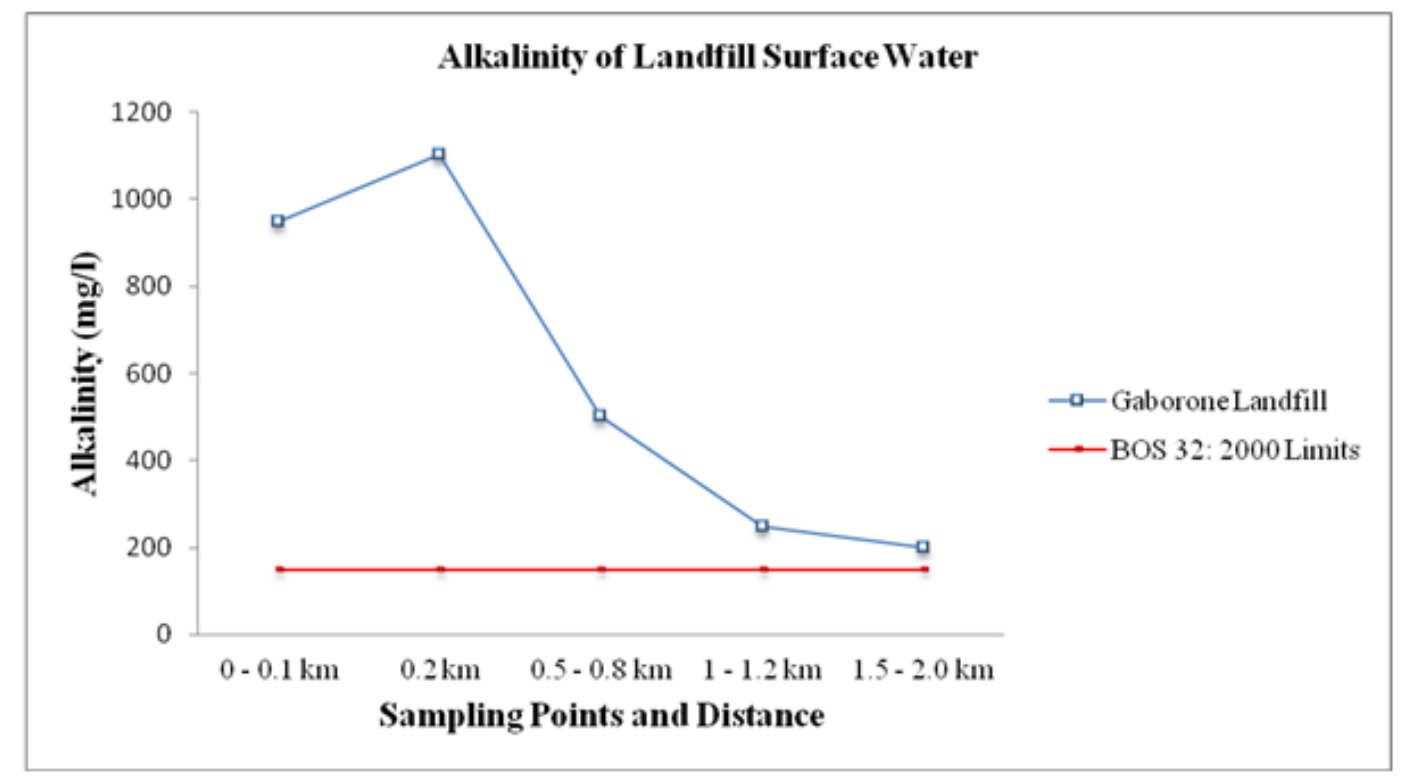

Source: Author's Findings (2012)

Figure 8. Alkalinity of Landfill Surface Water

Table 1. Classification of Surface Water Quality Based on $\mathrm{BOD}_{5}$ values

\begin{tabular}{cc}
\hline DEGREE & $\left(\mathbf{B O D}_{\mathbf{5}}\right)\left(\mathbf{O 2} \mathbf{~ m g ~ l}^{\mathbf{1}}\right)$ \\
\hline Very Clean & $<1.0$ \\
Clean & $1.1-1.9$ \\
Moderately Polluted & $2.0-2.9$ \\
Polluted & $3.0-3.9$ \\
Very Polluted & $4.0-10.0$ \\
Extremely Polluted & $>10.0$ \\
\hline
\end{tabular}

Source: Radojevic and Bashkin (1999) 


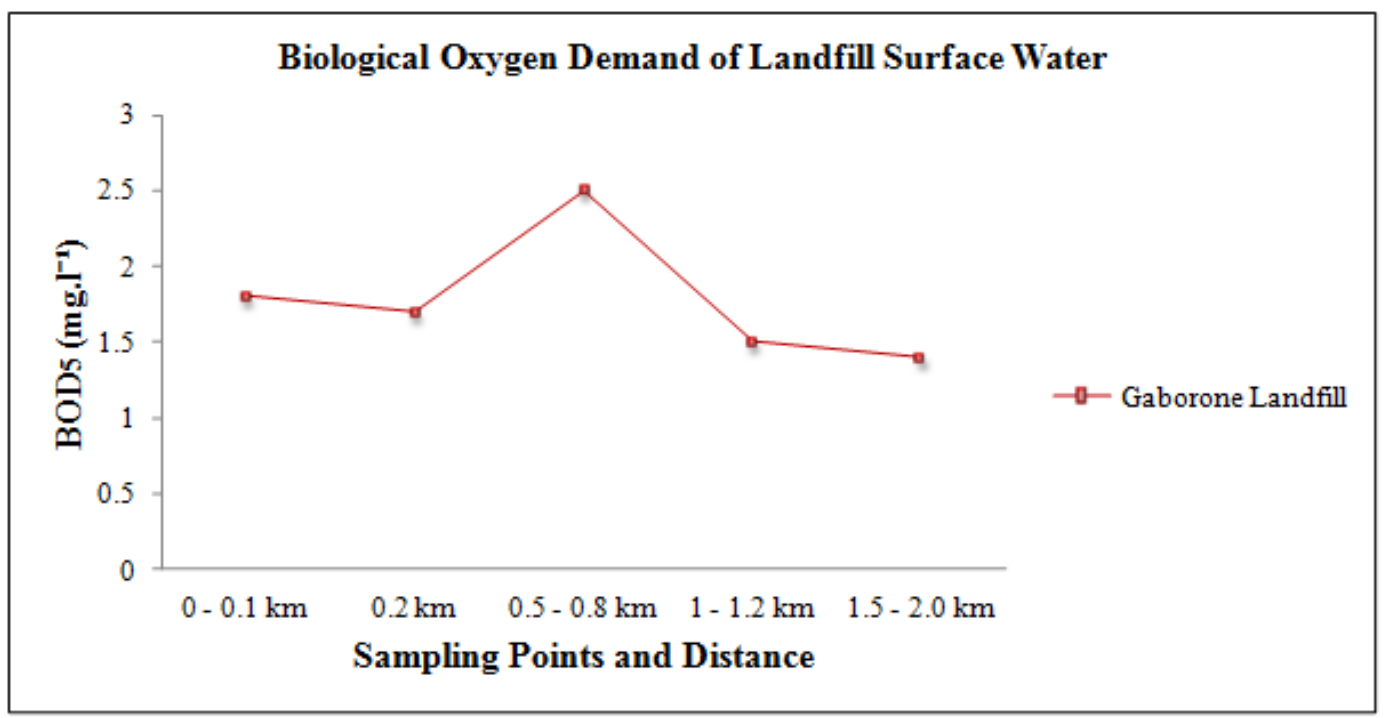

Figure 9. Biological Oxygen Demand of Landfill Surface Water

\section{Phosphates $\left(\mathrm{PO}_{4}^{3-}\right)$, Nitrates $\left(\mathrm{NO}_{3}^{-}\right.$, Sulphates $\left(\mathrm{SO}_{4}^{2-}\right)$ and Ammonia $\left(\mathrm{NH}_{3}\right)$ Levels}

All the surface water samples have a mean phosphate $\left(\mathrm{PO}_{4}^{3-}\right)$ level of $0.22 \mathrm{mg} \cdot 1^{-1}$ above the USEPA drinking water set standard $\left(0.1 \mathrm{mg}^{-1} \mathrm{l}^{-1}\right)$, (Table 2). The level is similar to that of other studies carried out earlier (Areola, Segosebe and Gwisai, 2015; Osei et al., 2011; Raman and Sathiya - Narayanan, 2008; Longe and Enekwechi, 2007). The current levels could be due to waste materials from the landfill such as animal waste and fertilizers as revealed in previous studies (Longe and Balogun, 2010; Raman and Sathiya - Narayanan, 2008). There is a gradual increase in $\mathrm{PO}_{4}^{3-}$ levels with increasing distance (Figure 10). The Gaborone could be due to the amount of waste and other sources of waste deposition independent of the landfill that could have led to high $\mathrm{PO}_{4}^{3-}$ levels in Gaborone surface waters (Alslaibi, Mogheir and Afifi, 2011; Steinnes et al., 1997).

Table 2. Mean values for physico - chemical parameters of surface water in Gaborone

\begin{tabular}{|c|c|c|c|c|c|}
\hline Parameter & $\begin{array}{c}\text { Gaborone Landfill Mean } \\
\text { Values }\end{array}$ & WHO & USEPA & BOS 2000 & EU Limits \\
\hline $\mathrm{pH}$ & 8.12 & 6.5 & 6.5 & 6.5 & 7.5 \\
\hline EC $\left(\mu \mathrm{s}, \mathrm{cm}^{-1}\right)$ & 1064.3 & - & - & 3100 & 44.6 \\
\hline Colour (TCU) & 12.8 & - & 15 & 15 & - \\
\hline TDS (mg) & 744 & 500 & 500 & 450 & - \\
\hline Turbidity (NTU) & 5.62 & 6 & 5 & 0.5 & - \\
\hline Alkalinity $\left(\mathbf{m g} \mathbf{l}^{-1}\right)$ & 600.20 & - & - & 150 & - \\
\hline $\mathrm{BOD}_{5}\left(\mathrm{mgl}^{-1}\right)$ & 1.78 & - & - & - & - \\
\hline $\mathrm{PO}_{4}^{3-}\left(\mathrm{mg}_{x} \mathrm{I}^{-1}\right)$ & 0.22 & - & 0.1 & - & - \\
\hline $\mathrm{NO}_{3}^{-}\left(\mathrm{mg} \mathrm{I}^{-1}\right)$ & 29.06 & 50 & - & 45 & 9.07 \\
\hline $\mathrm{SO}_{4}^{2-}\left(\mathrm{mg}_{\mathrm{x}} \mathrm{I}^{-1}\right)$ & 447.3 & 250 & 250 & 200 & 52.1 \\
\hline $\mathrm{NH}_{3}\left(\mathrm{mg}_{\mathrm{N}} \mathrm{I}^{-1}\right)$ & 6.12 & 1.5 & - & 0.2 & - \\
\hline$\frac{36}{17} \mathrm{Cl}^{-}\left(\mathrm{mg}^{-1}\right)$ & 2290.92 & 250 & 250 & 100 & 33.3 \\
\hline
\end{tabular}

Nitrates $\left(\mathrm{NO}_{3}^{-}\right)$in water samples of Gaborone landfills have a mean of $29.06 \mathrm{mg}^{-1} \mathrm{l}^{-1}$ (Table 2). The range (20.93 $46.51 \mathrm{mg} .1^{-1}$ is similar to that of other studies conducted earlier showing an appreciable presence of pollutants in all the water samples (Akinbile, 2012; Alslaibi, Mogheir and Afifi, 2011; Longe and Balogun, 2010); while other findings are far lower than for the current study and set thresholds for drinking water (Sholichin, 2012; Osei et al., 2011; Al - Sabahi et al., 2009; Raman and Sathiya - Narayanan, 2008; Longe and Enekwechi, 2007; Salminen, 2005). However the $\mathrm{NO}_{3}^{-}$levels of the current study are below the set standards (NSDWQ, 2007; WHO, 2004; BOS 32: 2000). All samples except the 0.2 $\mathrm{km}$ [which is similar to previous studies (Gvozdic et al., 2012)] are below the BOS 32:2000 drinking water standard (45 $\left.\mathrm{mg} . \mathrm{l}^{-1}\right)$, and the WHO drinking water standard (50 mg. $\left.\mathrm{l}^{-1}\right)$ although above the EU limits (Table 2). There is a general decline in $\mathrm{NO}_{3}^{-}$levels with increasing distance from the landfill. 
Sulphate $\left(\mathrm{SO}_{4}^{2-}\right)$ levels are higher than the set standards for all the samples (Figure 10 and Table 2), (WHO, 2004; USEPA, 1991). The concentration range for all the samples is $353.7-651.6 \mathrm{mg} . \mathrm{l}^{-1}$ which is statistically significantly higher than for other studies in other developing and developed countries indicating toxic pollution from the landfill waste (Osei et al., 2011; Longe and Balogun, 2010; Raman and Sathiya - Narayanan, 2008; Longe and Enekwechi, 2007; Salminen, 2005). Indeed, some prior studies have shown that landfills may pollute surface waters with high $\mathrm{SO}_{4}^{2-}$ levels by as much as $784 \mathrm{mg} .1^{-1}$ (Le Seur Spencer and Drake, 1987). The general trend shows that there is a decline in concentration of $\mathrm{SO}_{4}^{2-}$ downstream with an increase in distance from the landfill. However, this is contrary to the findings by Osei et al., (2011), which indicate increased $\mathrm{SO}_{4}^{2-}$ levels with increasing distance.
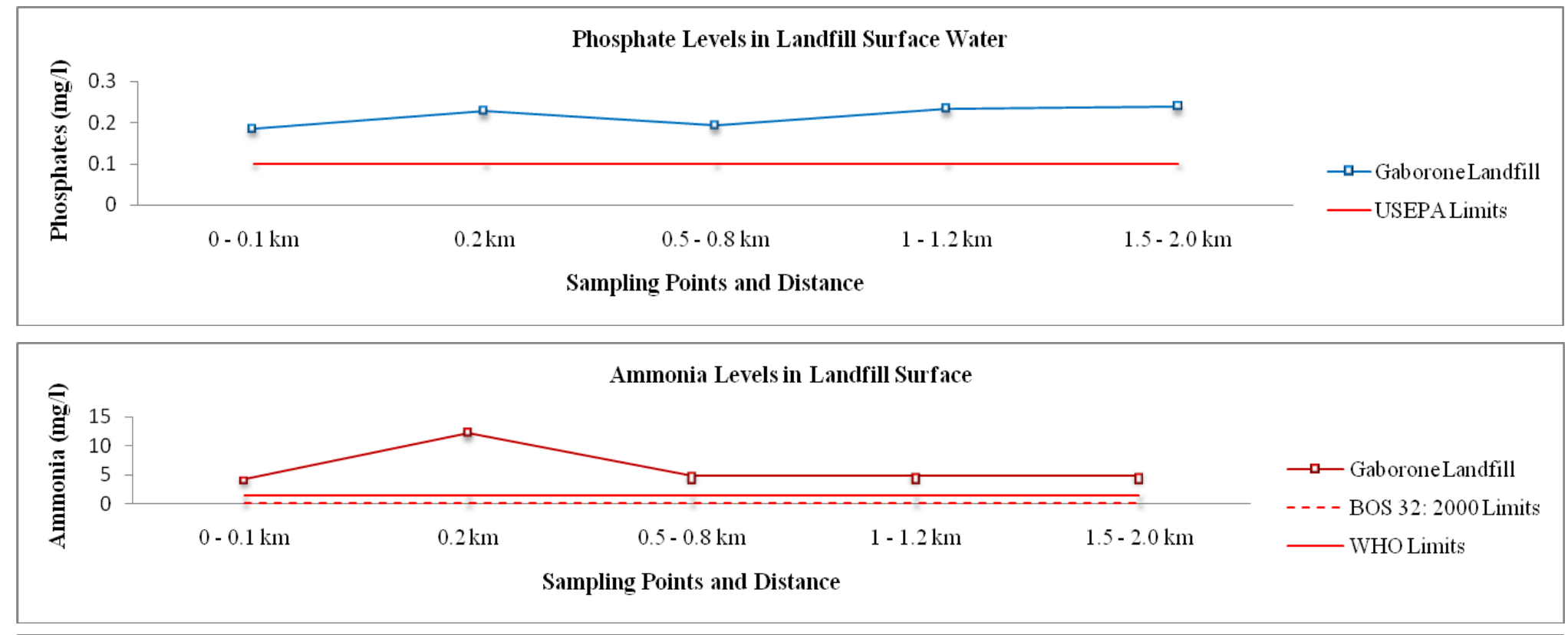

\begin{tabular}{|c|c|c|c|c|c|c|}
\hline \multicolumn{7}{|c|}{ Nitrate Levels in Landfill Surface Water } \\
\hline \multirow{2}{*}{ 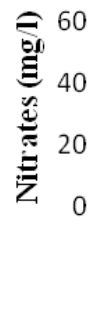 } & \multirow[t]{2}{*}{$0-0.1 \mathrm{~km}$} & $0.2 \mathrm{~km}$ & $0.5-0.8 \mathrm{~km}$ & $1-1.2 \mathrm{~km}$ & $1.5-2.0 \mathrm{~km}$ & $\begin{array}{l}\text { —— Gaborone Landfill } \\
-- \text { - - BOS 32: 2000 Limit } \\
\longrightarrow \text { WHO Limits }\end{array}$ \\
\hline & & & Points and & & & \\
\hline
\end{tabular}



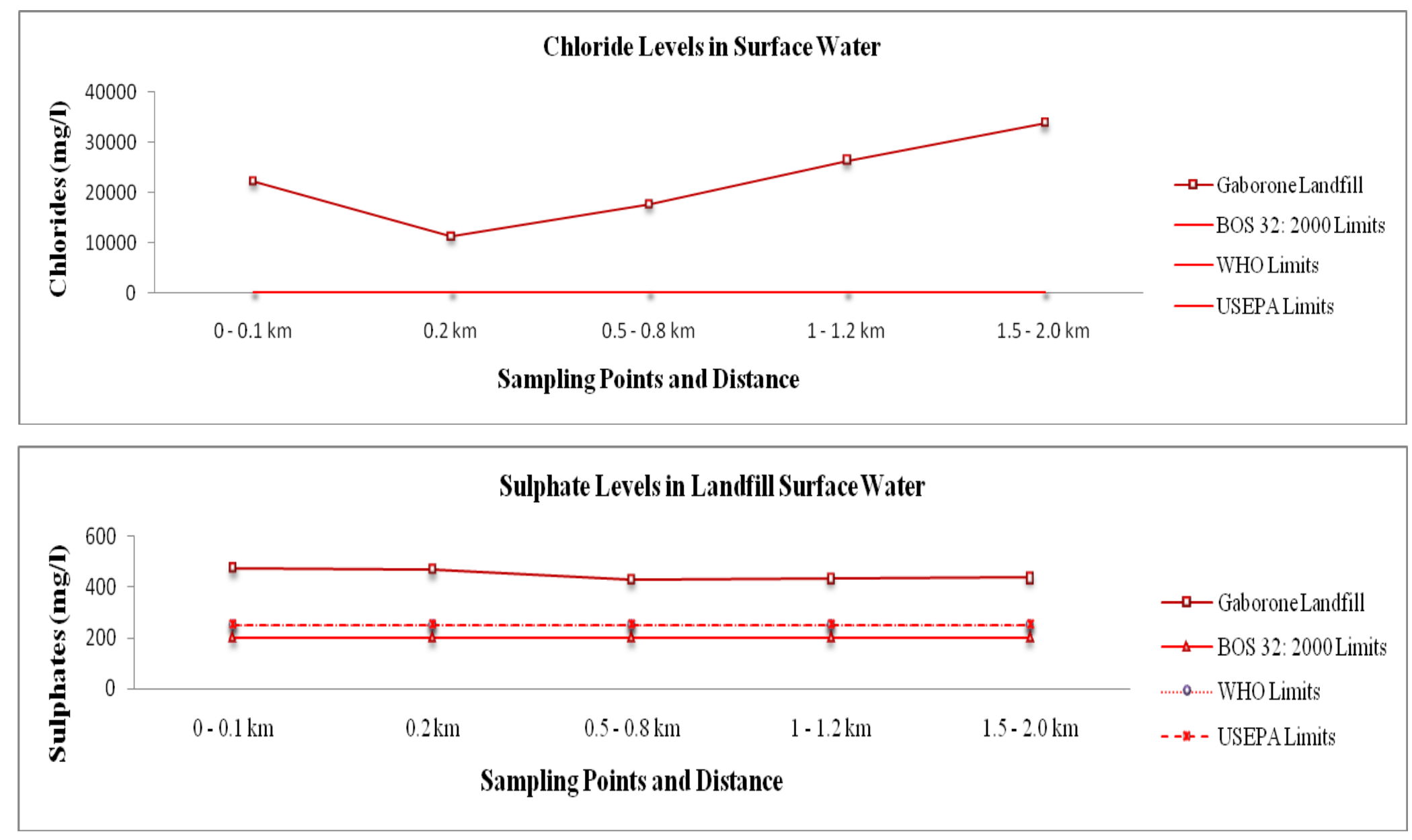

Figure 10. Gaborone Landfill Surface Water Levels $\mathrm{PO}_{4}^{3-}, \mathrm{NH}_{3} \mathrm{NO}_{3}^{-}, \mathrm{Cl}^{-}$and $\mathrm{SO}_{4}^{2-}$ 
The concentration of Ammonia $\left(\mathrm{NH}_{3}\right)$ in Gaborone is

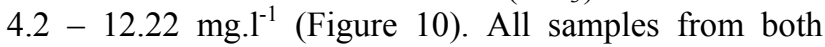
landfills have $\mathrm{NH}_{3}$ levels above the set Botswana and WHO drinking water limits, which are $0.2 \mathrm{mg} .1^{-1}$ and 1.5 mg. $1^{-1}$ respectively (Figure 10 and Table 2), (BOS 32: 2000; WHO, 2004). This is an indication of pollution from waste materials as the $\mathrm{NH}_{3}$ levels are higher than in prior studies (Gvozdic et al., 2011; Alslaibi, Mogheir and Afifi, 2011; $\mathrm{Al}$ - Sabahi et al., 2009; Longe and Enekwechi, 2007). There is a general decline in $\mathrm{NH}_{3}$ levels with increasing distance from the landfill (Longe and Balogun, 2010).

\section{Chlorides $\left({ }_{17}^{36} \mathrm{Cl}^{-}\right)$Concentration}

Chlorides $\left({ }_{17}^{36} \mathrm{Cl}^{-}\right)$concentrations for all the surface water samples range from 8224.4 - $37577 \mathrm{mg} . \mathrm{l}^{-1}$ (Figure 10). The ${ }_{17}^{36} \mathrm{Cl}^{-}$levels of the current study are statistically significantly higher than those of prior measurements conducted in other developing countries (Akinbile, 2012; Alslaibi, Mogheir and Afifi, 2011; Longe and Balogun, 2010; Al - Sabahi et al., 2009; Longe and Enekwechi, 2007; Salminen, 2005; Jeevan Rao and Shantaram, 2003). The high ${ }_{17}^{36} \mathrm{Cl}^{-}$levels indicate pollution from landfill waste which requires treatment before use (Igbinosa and Okoh, 2009). All samples are above the set Botswana, WHO and USEPA drinking water limits, which are 100, 250, and 250 mg..$^{-1}$ respectively (Figure 10 and Table 2), (Raman and Sathiya - Narayanan, 2008; WHO, 2004; BOS 32:2000; USEPA, 1991). There is a sharp increase in ${ }_{17}^{36} \mathrm{Cl}^{-}$levels with increasing distance from the landfill. This could be due to livestock which utilize the surface water sources for drinking. However this is contrary to the findings of prior studies (Alslaibi, Mogheir and Afifi, 2011).

\section{Hexavalent Chromium $\left({ }_{24}^{52} \mathrm{Cr}^{6+}\right)$ and Copper $\left({ }_{29}^{64} \mathrm{Cu}^{2+}\right)$ Concentration}

All samples have ${ }_{24}^{52} \mathrm{Cr}^{6+}$ concentration in the range $0.004-0.02 \mathrm{mg} . \mathrm{l}^{-1}$ which is below the set limits (Figure 11). Though appreciable the ${ }_{24}^{52} \mathrm{Cr}^{6+}$ concentrations in the waters are below the set drinking standards of $0.05 \mathrm{mg} . \mathrm{l}^{-1}$ (Gvozdic et al., 2011; Osei et al., 2011; Raman and Sathiya - Narayanan, 2008). The results are similar to those of previous studies conducted in developing countries (Raman and Sathiya - Narayanan, 2008; Longe and Enekwechi, 2007). On the other hand some studies reveal that water samples have statistically significantly high ${ }_{24}^{52} \mathrm{Cr}^{6+}$ levels as compared to the current study (Longe and Balogun, 2010, Salminen, 2005). ${ }_{24}^{52} \mathrm{Cr}^{6+}$ concentration gradually increases with distance from the landfill. Similarly prior findings show the same pattern of ${ }_{24}^{52} \mathrm{Cr}^{6+}$ levels downstream (Al - Sabahi et al., 2009).

${ }_{29}^{64} \mathrm{Cu}^{2+}$ was detected in only one sample $(0-0.1 \mathrm{~km})$ from the Gaborone landfill at $0.054 \mathrm{mg} \cdot \mathrm{l}^{-1}$. The ${ }_{29}^{64} \mathrm{Cu}^{2+}$ level is lower or similar as compared to other research studies conducted earlier (Gvozdic et al., 2011; Osei et al., 2011; Tamunobereton - ari, Omubo - Pepple and Tamunobereton - ari, 2010; Al - Sabahi et al., 2009; Longe and Enekwechi, 2007; Salminen, 2005; Haertling, 1989). The sample is the closest to the landfill indicating waste influence and pollution downstream. ${ }_{29}^{64} \mathrm{Cu}^{2+}$ is not detected in all the other samples suggesting that ${ }_{29}^{64} \mathrm{Cu}^{2+}$ could have been adsorbed by the soil strata or by the soil organic matter (Akinbile, 2012; Alslaibi, Mogheir and Afifi, 2011; Al - Sabahi et al., 2009; Suman et al., 2006).

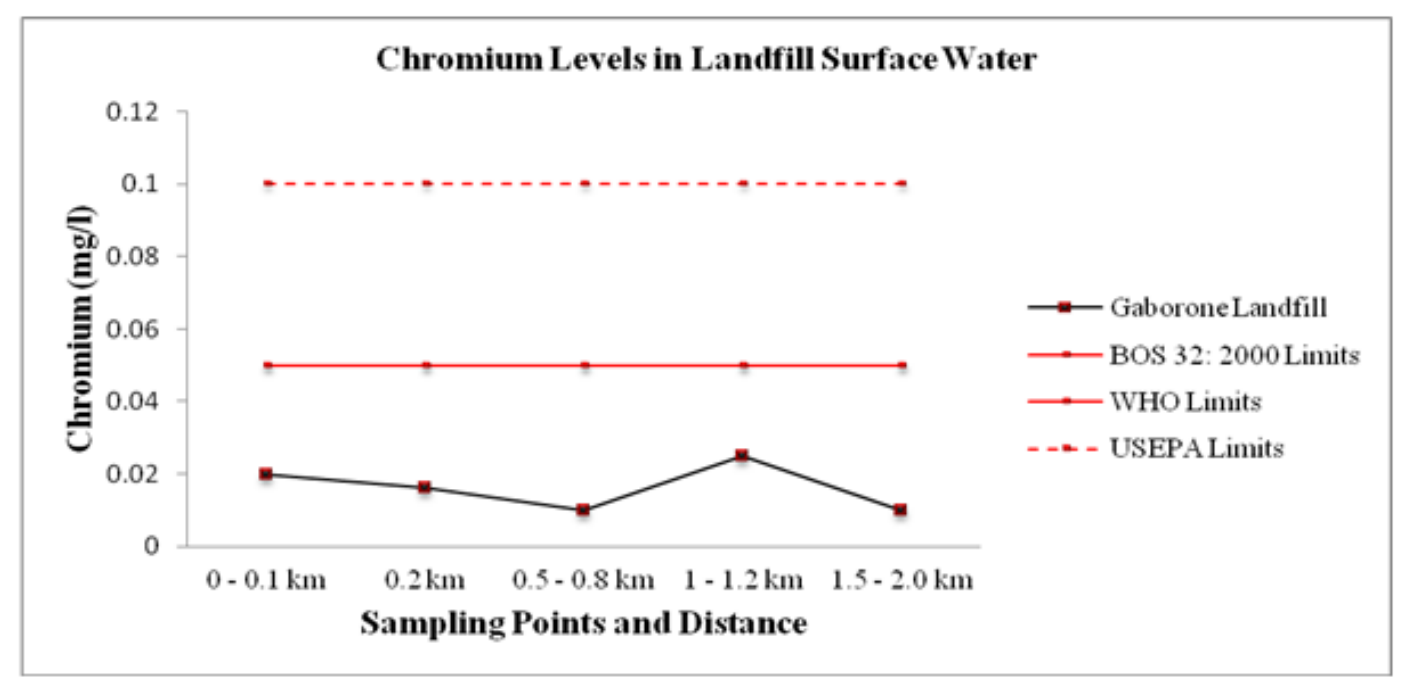

Figure 11. Chromium Levels in Landfill Surface Water 


\section{Sodium $\left({ }_{11}^{23} \mathrm{Na}^{+}\right)$and Potassium $\left({ }_{19}^{39} \mathrm{~K}^{+}\right)$Concentration}

The concentration range of ${ }_{11}^{23} \mathrm{Na}^{+}$in the surface water samples for Gaborone landfill is $42.18-120.92 \mathrm{mg} . \mathrm{l}^{-1}$. All the samples are below the WHO (200 mg. $\left.\mathrm{l}^{-1}\right)$ drinking standards, while the majority of the samples are below the Botswana $\left(100 \mathrm{mg} . \mathrm{l}^{-1}\right)$ drinking water threshold; on the other hand all samples are above the USEPA $\left(10 \mathrm{mg} . \mathrm{l}^{-1}\right)$ and EU limits $(23.1$ mg..$^{-1}$ ) of drinking water respectively (Figure 12 and Table 3). The ${ }_{11}^{23} \mathrm{Na}^{+}$levels of the current study are statistically significantly higher than levels observed in other studies (Al Sabahi et al., 2009; Haertling, 1989). The impact of the landfill on the water samples appears to be limited based on the Botswana and WHO standards (BOS 32: 2000; WHO, 2004). The $0.5-0.8 \mathrm{~km}$ sample has the highest ${ }_{11}^{23} \mathrm{Na}^{+}$level as compared to others, and a similar trend is observed among previous studies suggesting anthropogenic factors (Alslaibi, Mogheir and Afifi, 2011; Steinnes et al., 1997).

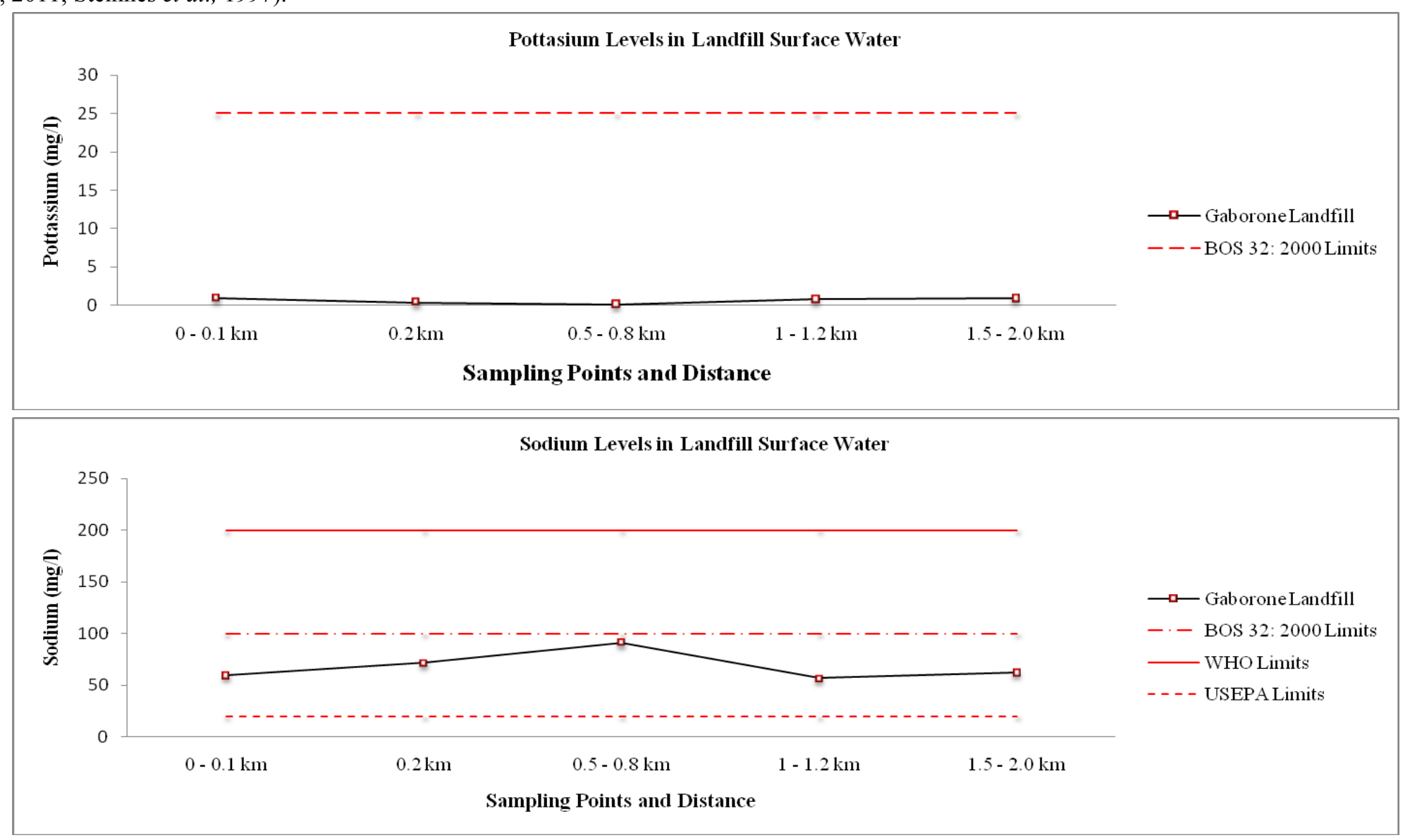

Figure 12. Sodium and Potassium Levels in Landfill Surface Water 

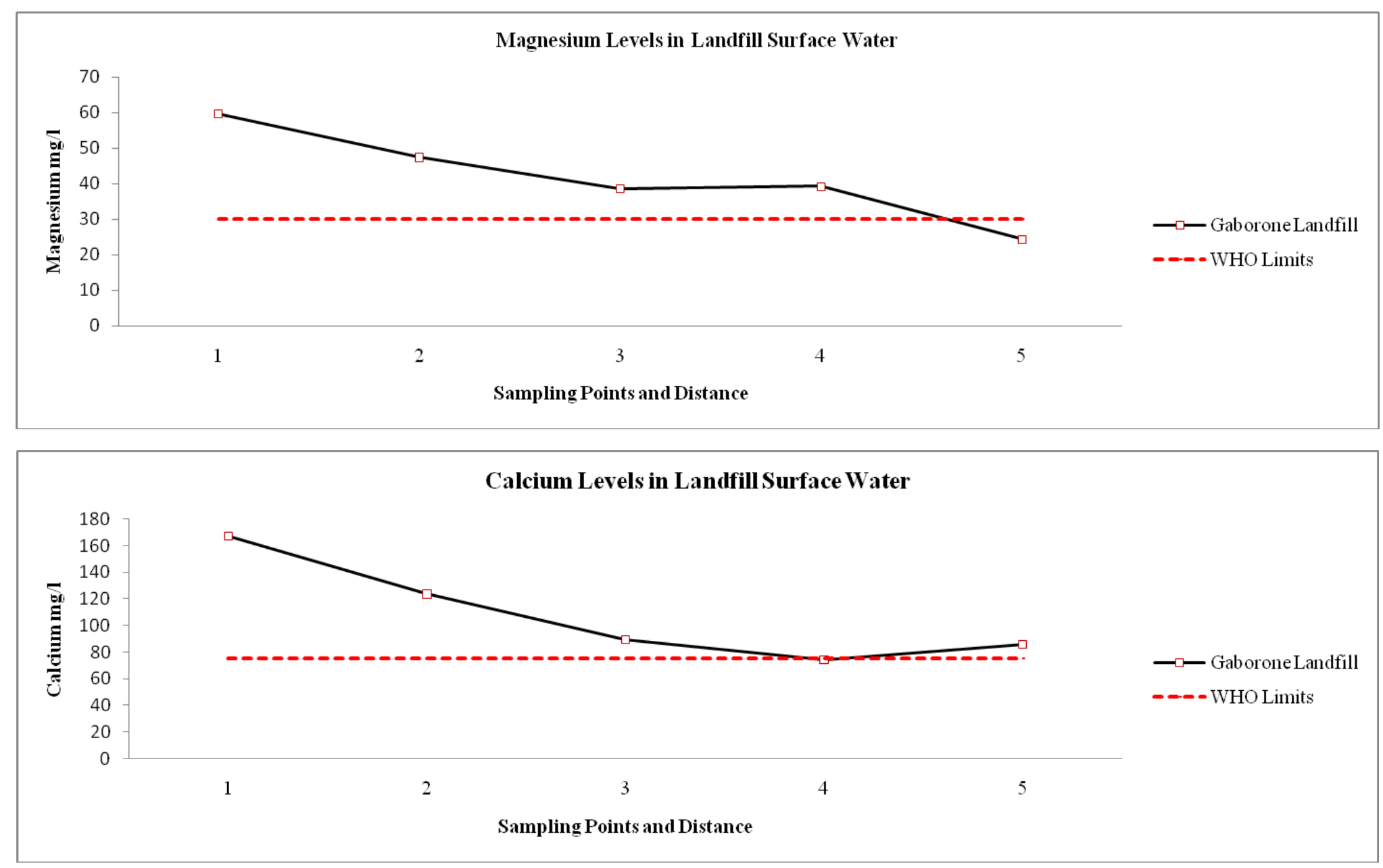

Figure 13. Calcium and Magnesium Levels in Landfill Surface Water 
Table 3. Mean values for heavy metals of surface water in Gaborone.

\begin{tabular}{cccccc}
\hline Parameter & $\begin{array}{c}\text { Gaborone Landfill } \\
\text { Mean Values }\end{array}$ & WHO & USEPA & BOS 2000 & EU Limits \\
\hline${ }_{24}^{52} \mathrm{Cr}^{6+}\left(\mathrm{mg}^{-1}\right)$ & 0.02 & 0.05 & 0.1 & 0.05 & 0.792 \\
${ }_{64}^{69} \mathrm{Cu}^{2+}\left(\mathrm{mg}^{-1}\right)$ & 0.05 & $1-2$ & 1.3 & - & 1.23 \\
${ }_{23}^{23} \mathrm{Na}^{+}\left(\mathrm{mg}^{-1}\right)$ & 68.17 & 200 & 20 & 100 & 23.1 \\
${ }_{39}^{19} \mathrm{~K}^{+}\left(\mathrm{mg}^{-1}\right)$ & 0.61 & - & - & 25 & 3.07 \\
${ }_{20}^{40} \mathrm{Ca}^{2+}\left(\mathrm{mg}^{-1}\right)$ & 107.86 & 75 & - & - & 55.2 \\
${ }_{12}^{24} \mathrm{Mg}^{2+}\left(\mathrm{mg}^{-1} \mathrm{l}^{-1}\right)$ & 41.76 & 30 & - & - & 11.5 \\
\hline
\end{tabular}

Source: Authors Findings (2012)

The range for ${ }_{19}^{39} \mathrm{~K}^{+}$concentrations in Gaborone is $\left(0.145-0.8977 \mathrm{mg} . \mathrm{l}^{-1}\right)$, (Figure 12). However, all the samples are below the set drinking water limits in Botswana $\left(25 \mathrm{mg} \cdot \mathrm{l}^{-1}\right)$, EU countries $\left(12 \mathrm{mg} \cdot \mathrm{l}^{-1}\right)$ and Canada (10 mg. $\mathrm{l}^{-1}$ ), (Salminen, 2005; Radojevic and Bashkin, 1999). Similarly other studies show that ${ }_{19}^{39} \mathrm{~K}^{+}$levels are lower than the set thresholds of international organizations and country regulations (Al - Sabahi et al., 2009; YMWE, 1999). However, some studies have recorded very high ${ }_{19}^{39} \mathrm{~K}^{+}$levels beyond the set limits (Haertling, 1989). There is a general decline in ${ }_{19}^{39} \mathrm{~K}^{+}$levels with increasing distance from the landfill as observed in other literature (Omoniyi and Ogunsanwo, 2009).

\section{Calcium $\left({ }_{20}^{40} \mathrm{Ca}^{2+}\right)$ and Magnesium $\left({ }_{12}^{24} \mathrm{Mg}^{2+}\right)$ Concentration}

The range for ${ }_{20}^{40} \mathrm{Ca}^{2+}$ concentrations is $54.67-167.1$ mg..$^{-1}$ for both Gaborone samples (Figure 13). Most of the surface water samples are above the WHO and EU drinking water threshold as observed by prior studies (Longe and Enekwechi, 2007; Salminen, 2005; WHO, 2004; Le Seur Spencer and Drake, 1987). However, some studies have shown lower ${ }_{20}^{40} \mathrm{Ca}^{2+}$ levels than the current study (Haertling, 1989). There is a general decline in ${ }_{20}^{40} \mathrm{Ca}^{2+}$ levels with increasing distance from the landfill. The same spatial trend has been observed by studies in some developing nations (Akinbile, 2012; Al - Sabahi et al., 2009). This indicates the influence of waste materials disposed of at the landfill site (Van Lynden, Mantel and Van Oostrum, 2004).

The range for ${ }_{12}^{24} \mathrm{Mg}^{2+}$ concentrations is $(24.37-59.48$ $\left.\mathrm{mg} . \mathrm{l}^{-1}\right)$ for Gaborone surface water samples (Figure 13). On the other hand some studies have recorded higher ${ }_{12}^{24} \mathrm{Mg}^{2+}$ levels than for the current study (Le Seur Spencer and Drake, 1987). There is a significant general decline in ${ }_{12}^{24} \mathrm{Mg}^{2+}$ levels with increasing distance from the landfill $(r$ $=-0.9439, p=\leq 0.05$ with a $R^{2}=0.8909$ ), and the trend appears to be similar to that of previous studies (Al Sabahi et al., 2009). Most of the samples at the landfill are above the set WHO and EU limits, (Salminen, 2005; WHO, 2004). On the other hand most studies have shown that ${ }_{12}^{24} \mathrm{Mg}^{2+}$ levels are higher downstream than upstream (Haertling, 1989; Le Seur Spencer and Drake, 1987; WHO, 1984).

\section{Conclusions}

All of the surface water samples were alkaline and there was a general decline in $\mathrm{pH}$ values with increasing distance from the landfill sites. On the other hand the $\mathrm{pH}$ was higher than the BOS 32: 2000, WHO and USEPA limits. Some water samples in Gaborone closer to the landfill surpassed the set colour limits.

Alkalinity levels were higher than BOS 32: 2000 limits. The $\mathrm{BOD}_{5}$ test showed that the surface water samples were moderately polluted. All surface water samples had phosphate levels above the USEPA set limits, while some samples had surpassed the nitrates limits in Botswana. All samples from the landfill had sulphate, chloride and ammonia concentration levels which were above the set limits (USEPA, WHO and BOS 32:2000). The sodium concentrations were above the USEPA set limits. Calcium and Magnesium samples close to the landfill were above the WHO limits for Gaborone landfill.

\section{Acknowledgements}

The authors are thankful to the Department of Environmental Science at the University of Botswana for the support to carry out the study and the Gaborone City Council, Department of Environmental Health.

\section{REFERENCES}

[1] Abdelatif, M.A. (2001). Assessing of Sri Petaling Landfill Towards Pollution in an Uncofined Aquifer, $\mathrm{PhD}$ Thesis, University of Putra, Malaysia.

[2] Abd Malek, Z.D., Hassan M.N., and Sapari, N. (1996). Technological and Economic Evaluation of Solid Waste Scavenging and Recyling Practices. Pertanika Journal of Science and Technology, 4(1), $115-130$.

[3] Akinbile, C.O. (2012). Hawked Water Quality and Its Health Implications in Akure, Nigeria. Botswana Journal of Technology, 15, $70-75$.

[4] Alloway, B.J. (Ed.) (1995). Heavy Metals in Soils, Second Edition, Blackie Academic and Professional, Glasgow UK.

[5] Al - Sabahi, E., Abdul - Rahim, S., Wan Yacob, W.Z.B., Al 
- Nozaily, F., and Alshaebi, F. (2009). A Study of Surface Water and Groundwater Pollution in Ibb City, Yemen. American Journal of Environmental Sciences, 5(3), 256-266.

[6] Alslaibi, T.M., Mogheir, Y.K., and Afifi, S. (2011). Assessment of Groundwater Quality due to Municipal Solid Waste Landfills Leachate. Journal of Environmental Science and Technology 4(4), $419-436$.

[7] Al - Rawas, G.A., and Valeo, C. (2011). Spatial Assessment of Water Quality Data in A'Seeb Area, Oman using GIS. Magazine.geotunis.org (Accessed 17/11/12).

[8] Areola, O.O., Segosebe, E. M., and Gwisai, R.D. (2015). Assessing Physico-Chemical Pollutants and Heavy Metals in Water Sources around Lobatse Sanitary Landfill in Botswana. Open Journal of Applied and Theoretical Environmental Sciences 1(1), 31 - 55.

[9] Bada, B.S., and Olarinre, T. A. (2012). Characteristics of Soils and Heavy Metal Content of Vegetation in Oil Spill Impacted Land in Nigeria. Proceedings of the Annual International Conference on Soils, Sediments, Water and Energy, 17(2), $1-10$.

[10] Bhambulkar, A.V. (2011). Effects of Leachate Recirculation on a Landfill. International Journal of Advanced Engineering Sciences and Technologies 11(2), 286- 291.

[11] BOS 32 (2000). Botswana Water Quality Guidelines. Botswana Bureau of Standards.

[12] Chattopadhyay, S., Dutta, A., and Ray, S. (2008). Municipal Solid Waste Management in Kolkata, India: - A Review. Waste Management, 29, 1449 - 1458.

[13] Chofqi, A., Younsi, A., Lhadi, E. K., Mania, J., Mudry, J., and Veron, A. (2004). Environmental Impact of an Urban Landfill on a Coastal Aquifer (El Jadida, Morocco). Laboratory of Environmental Techniques and Geosciences, Faculty of Science, El Jadida, Morocco. Journal of African Earth Sciences, 39, $509-516$

[14] Christensen, J. B., and Christensen, T. H. (1999). Complexation of $\mathrm{Cd}, \mathrm{Ni}$ and $\mathrm{Zn}$ by DOC in Polluted Groundwater: A Comparison of Approaches using Resin Exchange, Aquifer Material Sorption, and Computer Speciation Models (WHAM and MINTEQA2). Journal of Environmental Science and Technology, 33, 3857- 63.

[15] Domska, D., and Warechowska, M. (2008). The Effect of the Municipal Waste Landfill on the Heavy Metals Content in Soil. Chapter 4, $95-105$.

[16] Edosomwan, N.L., and Onwumah, B.I. (2008). Impact of Municipal Solid Waste on some Soil Properties in Central Southern Nigeria. Indian Journal of Agricultural Research, 42(4), $244-251$.

[17] Elliot, P. (2006). Risk of Congenital Anomalies in Relation to Geographic Density of Landfill Sites in England. In: ISEE, September 3-6, 2006, Paris.

[18] Government of Botswana (1998). Botswana Waste Management Act.

[19] Gvozdic, V., Cacic, L., Brana, J., Puntaric, D., Vidosavljevic, D. (2012). Chemometric Analysis of Groundwater Quality Data around Municipal Landfill and Paper Factory and their Potential Influence on Population's Health. Medicinski
Glasnik 9(1).

[20] Gwebu, T.D. (2003). Population, Development, and Waste Management in Botswana: Conceptual and Policy Implications for Climate Change. Environmental Management, 31,348 - 354.

[21] Haertling, J.W. (1989). Trace Metal Pollution from Municipal Waste Disposal site at Pangnirtung North West Territories. Arctic, 42,57 - 61 .

[22] Husain, T., Hoda A., and Khan R. (1989). Impact of Sanitary Landfill on Groundwater Quality. Research Institute, King Fahd University of Petroleum and Minerals, Saudi Arabia. Journal of Water, Air and Soil Pollution, 45,191 - 206.

[23] Igbinosa, E.O., and Okoh, A.I. (2009). Impact of Discharge Wastewater Effluents on the Physico - Chemical Qualities of a Receiving Watershed in a Typical Rural Community. International Journal of Environmental Science and Technology, 6, $1735-1742$.

[24] ISI (Indian Standards Institution), (1983). Specification for drinking water IS: 10500, New Delhi.

[25] Jaji, M.O., Bamgbose, O., Odukoya, O.O., and Arowolo, T.A. (2007). Water Quality assessment of Ogun River, south west Nigeria. Environmental Monitoring and Assessment, $133,473-482$.

[26] Jeevan Rao, K., and Shantaram, M.V. (2003). Soil and Water Pollution due to Open Landfills. Workshop on Sustainable Landfill Management, 27 - 38.

[27] Joel, O. F., and Amajuoyi, C.A. (2009). Determination of Selected Physico - Chemical Parameters and Heavy Metals in a Drilling Cutting Dumpsite at Ezeogwu - Owaza, Nigeria. Journal of Applied Science and Environmental Management 13 (2), $27-31$.

[28] Johnson, G.V., and Zhang, H. (2012). Cause and Effects of Soil Acidity. Oklahoma Cooperative Extension Fact Sheets. http://osufacts.okstate.edu (19/07/12).

[29] Khan, M.Z.A. and Agarwal, S.K. (2006). Environmental Management, APH, New Delhi.

[30] Le Seur Spencer, L., and Drake, L. D., (1987). Hydrogeology of an Alkaline Fly Ash Landfill in Eastern Iowa. Groundwater 25(5)519-526.

[31] Loncnar, M., Zupancic, M., Bukovec, P., and Justin, M.Z., (2010).Fate of Saline Ions of a Planted Landfill Site with Leachate Recirculation. Waste Management 30, 110 - 118.

[32] Longe, E.O., and Balogun, M.R. (2010). Groundwater Quality Assessment near a Municipal Landfill, Lagos, Nigeria. Research Journal of Applied Sciences, Engineering and Technology 2(1), $39-44$.

[33] Longe, E.O., and Enekwechi, L.O. (2007). Investigation on Potential Groundwater Impacts and Influence of Local Hydrogeology on Natural Attenuation of Leachate at a Municipal Landfill. International Journal of Environmental Science and Technology 4(1), 133 - 140.

[34] Lobatse Town Council (2002). Lobatse Development Plan 2 (2003-2009). Ministry of Local Government, Lobatse Town Council Urban Development Committee. Annual Report.

[35] Manyanhaire, I. O., Sigauke, E., and Munasirei, D. (2009). 
Analysis of Domestic Solid Waste Management System: A Case of Sakubva High Density Suburb in the City of Mutare, Manicaland Province, Zimbabwe. Journal of Sustainable Development in Africa, 11(2), 367 - 377.

[36] Masocha, M., and Tevera, D. (2003). Spatial Patterns, Environmental Threats and Public Health. Geographical Association of Zimbabwe, University of Zimbabwe, Harare. Geographical Journal of Zimbabwe, 33, 9-19.

[37] Matsa, M., and Mutekwa, T. (2009). From Cradle to Grave... and then What? The Role of Environmental Factors in the Distribution of Pollutants around the City of Gweru's Dumpsite. Journal for Sustainable Development in Africa, 11(1), $174-185$.

[38] Miguel, M.G., Belinassi, L., Domingues, L.M., Nour, E.A.A., and Pereira, S.Y. (2012). Variations of the Physical and the Chemical characteristics of Sanitary Landfill Leachate after percolation into Tropical Soils. Chemical Engineering Transactions, 28, 19-24.

[39] Miller, T. G. (1996). Living in the Environment: Principles, Connections and Solutions, Wadsworth Publishing Company, New York.

[40] Misra, V., and Pandey, S.D. (2004). Hazardous Waste, Impact on Health and Environment for Development of Better Waste Management Strategies in Future in India. Environment International, 31, 417- 431.

[41] Mohamed, A.F., Yaacob, W.Z.W., Taha, M.R., and Samsudin, A.R. (2009). Groundwater and soil vulnerability in the Langsat Basin Malaysia. European Journal of Scientific Research, 27, 628-635.

[42] Moyo, G., Keefe, D., and Sill, P. (1993). Zimbabwe's Environmental Dilemma, Yap (Eds), Cleaner Production and Consumption in Eastern and Southern Africa: Challenges and Opportunities, Weaver Press, Harare.

[43] Mwiganga, M., and Kansiime, F. (2005). The Impact of Mpererwe Landfill in Kampala-Uganda on the Surrounding Environment. Institute of Environment and Natural Resources, Makerere University, Kampala Uganda. Physics and Chemistry of the Earth, 30, 744-750.

[44] Ngole, V.M. (2000). Physico - Chemical Mineralogical and Chemical Characterization of the Subsurface Environment of Gaborone Landfill in Botswana. (MSc Thesis), University of Botswana, School of Graduate Studies, Department of Environmental Science, Gaborone, Botswana.

[45] Noel, C. (2010). Solid Waste Workers and Livelihood Strategies in Greater Port-au-Prince, Haiti. University of The West Indies, Institute for Sustainable Development, Environmental Management Unit, 13 Gibraltar Camp Way, Mona Campus, Kingston, Jamaica.

[46] NSDQW (2007). Nigerian Standard for Drinking Water Quality. Nigerian Industrial Standard NIS 554, Standard Organization of Nigeria, 30 .

[47] Nwachukwu, M.A., Feng, H., and Alinnor, J. (2010). Assessment of Heavy Metal Pollution in Soil and their Implications within and around Mechanic Villages. International Journal of Science and Technology 7(2), 347 358 .

[48] Ogedengbe, K., and Akinbile, C.O. (2004). Impact of
Industrial Pollutants on Quality of Ground and Surface Waters at Oluyole Industrial Estate, Ibadan, Nigeria. Nigerian Journal of Technological Development, 4, 139 144.

[49] Odukoya A, M., and Abimbola, A, F. (2010). Contamination Assessment of Surface and Groundwater within and around two Dumpsites. International Journal of Science and Technology, 7(2), 367-376, Spring 2010.

[50] Omoniyi, O., and Ogunsanwo, O. (2009). Environmental Geological Assessment of a Solid Waste Disposal Site: A Case of Ilorin, Southwestern, Nigeria. Nature and Science $1(6) 53-62$.

[51] Osei, J., Osae, S.K., Fianko, J.R., Adomako, D., Laar, C., Anim, A.K., Ganyaglo, S.Y., Nyarku, M., and Nyarko, E.S. (2011). The Impact of Oblogo Landfill Site in Accra Ghana on the Surrounding Environment. Research Journal of Environmental and Earth Sciences 3(6), 633 - 636.

[52] Radojevic, M., and Bashkin V. N. (1999). Practical Environmental Analysis. The Royal Society of Chemistry, Cambridge United Kingdom.

[53] Raman, N., and Sathiya - Narayanan, D. (2008). Impact of Solid Waste Effect on Ground Water and Soil Quality neared to Pallavaram Solid Waste Landfill Site in Chennai. Rasayan Journal of Chemistry 1(4), $828-836$.

[54] Salminen, R. (Ed.), (2005). Geochemical Atlas of Europe. Part 1. Background Information Methodology and Maps. Geological Survey of Finland. www.gsf.fi/publ/foregsatlas $(30 / 10 / 2012)$.

[55] Schenato, F., Schroder, N.T., and Martins, F.B. (2008). Assessment of Contaminated Soils by Heavy Metals in Municipal Solid Waste Landfills in Southern Brazil. WSEAS Transactions on Environment and Development, 9, 745 755 .

[56] Sholichin, M. (2012). Field Investigation of Groundwater Contamination from Solid Waste Landfill in Malang, Indonesia. International Journal of Civil and Environmental Engineering IJCEE - IJENS, 12(2)74-81.

[57] Shyamala, R., Shanti, M., Lalitha, P. (2008). Physico Chemical Analysis of Borewell Water Samples in Telungupalayam Area in Coimbatore District, Tamilnadu, India. E-Journal for Chemistry, 5, $924-929$.

[58] Steinnes, E., Allen, R.O., Petersen, H.M., Ramback, J.P. and Varskog, P. (1997). Evidence of Large - Scale Heavy Metal Contamination of Natural Surface Soils in Norway From Long - Range Atmospheric Transport. Science of the Total Environment, 205, 255 - 266.

[59] Strange K. (2002). Review of Environmental and Health Effects of Waste Management: Municipal Solid Waste and Similar Wastes. Department for Environment Food and Rural Affairs. United Kingdom.

[60] Suman, M., Khaiwal-Ravindra, R. Dahiya, P., and Chandra, A. (2006). Leachate Characterization and Assessment of Groundwater Pollution near Municipal Solid Waste Landfill Site. Environmental Monitoring and Assessment, 118, 435-456.

[61] Tamunobereton - ari, I., Omubo - Pepple, V.B., and Tamunobereton - ari, N.A. (2010). Speciation of Heavy 
Metals $(\mathrm{Cu}, \mathrm{Pb}, \mathrm{Ni})$ Pollutants and the Vulnerability of Groundwater Resource in Okrika of Rivers State, Nigeria. American Journal of Scientific and Industrial Research 2(1), $69-77$.

[62] The Botswana Gazette (2010). Gaborone Solid Waste management in a Mess. Wednesday, 19 May 2010, Gaborone, Botswana.info@gazettebw.com.

[63] USEPA (1991). Water Quality Criteria Summary, Poster of the Office of Science and Technology.

[64] Van Lynden, G.W.J., Mantel, S., and Van Oostrum, A. (2004). Guiding Principles for the Quantitative Assessment of Soil Degradation. With focus on Salinization, Nutrient decline and Soil Pollution. International Soil Reference and Information Centre. Food and Agriculture Organization of the United Nations, Rome.

[65] Vrijheid, M. (2000). Health Effects of Residence near Hazardous Waste Landfill Sites: A Review of Epidemiologic Literature. Environmental Health Perspectives 108 (1)101-112.

[66] WHO (2004). Guidelines for Drinking Water Quality. Volume 1, Recommendation. Third Edition, WHO, Geneva, Switzerland.

[67] WHO (1984). World Health Organization Guideline for Drinking Water Quality. Volume 1, Recommendation. WHO, Geneva, Switzerland.

[68] Wong, M.H. (1988). Soil and Plant Characteristics of Landfill Sites near Merseyside, England. Journal of Environmental Management 12(4), 491 - 499.

[69] Wong M.H., and Leung, K.C. (1989). Decontamination of Landfill Leachate by Soil Infiltration. Biomedical and Environmental Sciences, 2(4), 341 - 357.

[70] Wuana, R.A., and Okieimen, F.E. (2012). Heavy Metals in Contaminated Soils. A Review of Sources, Chemistry, Risks and Best Available Strategies for Remediation. International Scholarly Research Network, $1-20$.

[71] YMWE (1999). Yemen's Ministry of Water and Environment. Guidelines for Drinking Water Quality. Sana'a, Republic of Yemen. 